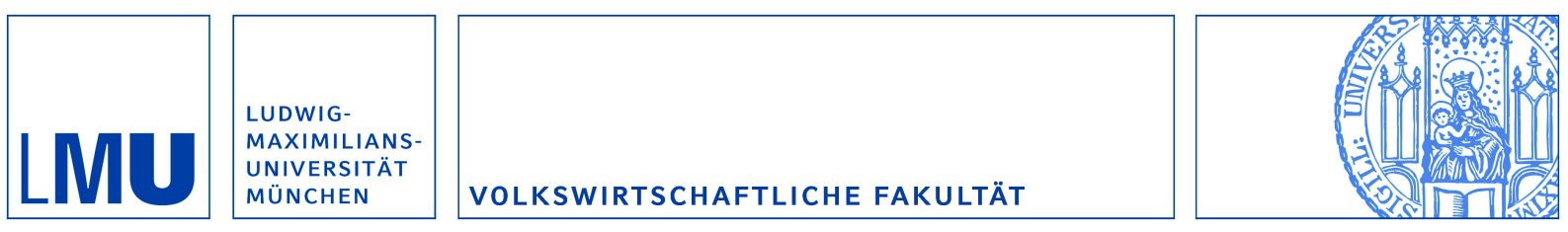

Schenkelberg, Heike:

Why are Prices Sticky? Evidence from Business Survey Data

Munich Discussion Paper No. 2011-2

Department of Economics

University of Munich

Volkswirtschaftliche Fakultät

Ludwig-Maximilians-Universitäł München

Online at https://doi.org/10.5282/ubm/epub. 12158 


\title{
Why are Prices Sticky? Evidence from Business Survey Data ${ }^{\underline{2}}$
}

\author{
Heike Schenkelberga,* \\ ${ }^{a}$ Munich Graduate School of Economics, Kaulbachstrasse 45 \\ 80539 Munich, Germany. Phone: +49-89-2180-6781
}

\begin{abstract}
This paper offers new insights on the price setting behaviour of German retail firms using a novel dataset that consists of a large panel of monthly business surveys from 1991-2006. The firm-level data allows matching changes in firms' prices to several other firm-characteristics. Moreover, information on price expectations allow analyzing the determinants of price updating. Using univariate and bivariate ordered probit specifications, empirical menu cost models are estimated relating the probability of price adjustment and price updating, respectively, to both time- and state- dependent variables. First, results suggest an important role for state-dependence; changes in the macroeconomic and institutional environment as well as firm-specific factors are significantly related to the timing of price adjustment. These findings imply that price setting models should endogenize the timing of price adjustment in order to generate realistic predictions concerning the transmission of monetary policy. Second, an analysis of price expectations yields similar results providing evidence in favour of state-dependent sticky plan models. Third, intermediate input cost changes are among the most important determinants of price adjustment suggesting that pricing models should explicitly incorporate price setting at different production stages. However, the results show that adjustment to input cost changes takes time indicating "additional stickiness" at the last stage of processing.
\end{abstract}

Keywords: Price setting behaviour, time dependent pricing, state dependent pricing, sticky prices

JEL: E31, E32, E50

\footnotetext{
${ }^{2 / 2}$ I would like to thank Kai Carstensen, Daniel Dias, Heinz Herrmann, Johannes Hoffmann, Gerhard Illing, Ulf von Kalckreuth, Harald Stahl and seminar participants at Deutsche Bundesbank and LMU Munich as well as participants at several conferences and workshops for helpful comments and suggestions. Financial support from the German Research Foundation through GRK 801 is gratefully acknowledged. All errors are my own.

${ }^{*}$ Corresponding author

Email address: heike.schenkelberg@lrz.uni-muenchen.de (Heike Schenkelberg)
} 


\section{Introduction}

The appropriate modeling of price stickiness has long been a major concern within the theoretical New-Keynesian literature. Recently, the improved availability of detailed price data paved the way for an increasing literature analyzing implications of micro price data for the different theoretical models of price setting. Understanding the exact mechanism underlying price adjustment decisions is important because competing models predict divergent effects of monetary policy and may lead to distinct welfare implications. ${ }^{1}$ This paper adds to this discussion by using a new dataset compiled by the Ifo Institute for Economic Research. The dataset consists of a large panel of monthly firm-level business surveys from January 1991 to January 2006 covering about 930 German retail firms. In the empirical analysis univariate and bivariate ordered probit menu cost models are specified and estimated in the spirit of the seminal target-threshold model by Cecchetti (1986). Within this empirical specification the probability of both price adjustment and price updating is related to a set of time- and state-dependent regressors. In particular, this paper contributes to the existing literature on various important dimensions. First, the determinants of price setting are analysed at the firm-level. Such an analysis has several advantages relative to an assessment at the item-level, which can be found in studies that use individual price records underlying CPI calculations. For instance, a firm-level assessment may lead to important implications for microfounded macro models. Second and related, relative to previous empirical studies on price setting the survey data allows matching changes in firms' prices to several other firm-characteristics. Thus, the empirical model explicitly captures the specific state of the individual firms, which is not possible using other types of price data. Third, because the price data can be linked to input costs on a product group-specific basis, I am able to explicitly analyze the transmission of price shocks through different production stages. Fourth, the dataset covers information on firms' expectations concerning future prices allowing an explicit evaluation of models concerned with the setting of pricing plans. An explicit analysis of the determinants of price updating has so far not been forthcoming within the empirical literature on price setting behaviour in retail.

More specifically, the empirical analysis offered in this paper covers three main issues. First, it will be assessed whether factors characterizing the economic environment of the firms are significant determinants for the probability of price adjustment next to time-dependent elements. In standard time-dependent models firms regularly adjust prices independently of the environment they are faced with (Taylor, 1980; Calvo, 1983). Therefore, the frequency of price setting is constant. Contrarily, state-dependent theories assume the timing of price changes to be the outcome of a profit maximization problem of firms; the probability of price adjustment thus

\footnotetext{
${ }^{1}$ For instance, Dotsey et al. (1999) show that prices adjust faster in state-dependent models leading to real effects of monetary policy that are less pronounced compared to the predictions of time-dependent models. For a thorough analysis of welfare implications of different models see e.g. Lombardo and Vestin (2008).
} 
depends on the state of the economy. ${ }^{2}$ In contrast to time-dependent models, therefore, both the size and the frequency of price adjustment vary with the state of the economy. Since the dataset at hand allows to examine the relative importance of the different regressors for the frequency of price changes it will be analyzed whether macroeconomic indicators like inflation or changes in the price of raw materials, accumulated since the last price change, or changes in the institutional environment are important for firms' price adjustment decision. Moreover, variables measuring the specific state of the firm such as changes in the overall state of business, the business volume, the number of orders or the expected business development are included in the regressions. These latter factors are considered in the analysis because recent price setting models stress the importance of firm-specific shocks for the price setting process. For instance, the model of Golosov and Lucas (2007) differentiates between firms' reaction to firm-specific and aggregate shocks and include both types of disturbances in a menu cost model. Moreover, imperfect information models as, for instance, Mackowiak et al. (2009), emphasize the importance of idiosyncratic shocks for price adjustment. ${ }^{3}$ My regression results suggest an important role for state-dependence; macroeconomic and institutional factors such as the sectoral rate of inflation, changes in the oil price or increases in the VAT rate are significantly related to the probability of price adjustment and have economically important effects. Moreover, factors characterizing the firm-specific environment as well as changes in intermediate input costs have highly significant effects. Thus, standard time-dependent pricing models predicting an exogenously given probability of price adjustment are not supported by the results.

The second question addressed is concerned with the price setting mechanism at different production stages. The question of whether the retail sector or preceding stages of production are dominant for the timing of price adjustment can have important implications for modeling price stickiness. ${ }^{4}$ In price setting models that explicitly include a production structure, intermediate inputs raise the degree of price stickiness because the pricing decisions of different firms become strategic complements and thus stickiness "adds up" through the production chain (Basu, 1995; Nakamura and Steinsson, 2008b). In these models prices of primary goods quickly adjust to macroeconomic shocks, while prices of goods at later stages of processing show a sluggish response to aggregate shocks but respond immediately to input price changes. Analyzing the degree of additional rigidity at the retail level thus helps to evaluate the predictions of these models. In particular, measures of changes in wholesale and manufacturing prices are related to the timing of price changes in the retail sector. First, the data generally promote pricing

\footnotetext{
${ }^{2}$ See e.g. Caplin and Spulber (1987), Dotsey et al. (1999), Gertler and Leahy (2008) and Golosov and Lucas (2007).

${ }^{3}$ The main motivation behind the inclusion of firm-specific factors is to improve the mapping of price setting features at the micro level into aggregate outcomes of theoretical pricing models by modeling the price setting process more realistically. The appropriate matching of micro data and aggregate results has been a major difficulty in modeling price setting. For instance, in the menu cost model of Caplin and Spulber (1987) prices are adjusted infrequently but still nominal shocks have no effects on the real economy. On the other hand, in models of imperfect information (Mackowiak and Wiederholt, 2009) monetary shocks have large and persistent real effects despite of frequent price adjustment. See also Mackowiak and Smets (2008) for a survey.

${ }^{4}$ See Nakamura (2008) for a discussion.
} 
models with intermediate inputs where stickiness "accumulates" through the production chain; changes in input costs are indeed among the most important determinants for price adjustment. Second, however, adding lags of input price measures shows that the effect of input cost changes on the probability of price adjustment in retail is rather persistent. This suggests that there is some degree of additional rigidity at the retail level, which is in line with empirical results of Nakamura (2008).

The third main issue analyzed in this paper concerns the updating of future price plans allowing to assess the plausibility of different sticky plan models. In these frameworks firms set entire plans prescribing the development of a sequence of future prices instead of individual prices at every period. The distinction between time- and state-dependence also applies to these models. On the one hand, in so-called sticky information models delayed price adjustment is the consequence of information costs that prevent continuous price revisions. ${ }^{5}$ These models predict that every period a fixed fraction of firms updates an entire sequence of future prices implying that the frequency of expected future price changes is constant over time. On the other hand, the sticky plan model of Burstein (2006) constitutes an example of state-dependent price updating. In this model firms' updating of pricing plans is constrained by a menu cost - the frequency of price updating is thus endogenous and adjusts once accumulated changes in the economic environment are large enough. ${ }^{6}$ While, so far, empirical evidence on the mechanism underlying the formation of pricing plans is scarce for the Euro area ${ }^{7}$, the dataset at hand allows to analyze these issues on a firm-specific level. In particular, relating the probability of a change in expectations of future prices to both time- and state-dependent variables, I evaluate the predictions of these respective sticky plan models. The results for price expectations are very similar to those for price realizations with most state-dependent variables turning out to be highly significant and economically important. This provides evidence in favour of statedependent sticky plan models.

The remainder of the paper is organized as follows. Section 2 gives a short review of the literature related to the issues addressed. In Section 3, the empirical strategy is outlined including a description of the business survey data, the empirical specification as well as the estimated price setting equations. In Section 4, the main results as well as robustness checks are given. Section 5 concludes.

\footnotetext{
${ }^{5}$ Examples include Bonomo and Carvalho (2004), Caballero (1989) and Mankiw and Reis (2002, 2006). While in Bonomo and Carvalho (2004) time-dependent price reviewing is due to the simultaneous occurrence of both menu and information costs, in Mankiw and Reis (2002, 2006) imperfect information is assumed to follow from a fixed cost of observing the state of the economy. See also Mankiw and Reis (2010) for an overview.

${ }^{6}$ Related to this model are recent contributions by, for instance, Alvarez et al. (2010) and Bonomo et al. (2010) modeling the mechanism underlying the price reviewing process. Due the inclusion of both menu and information costs these models assume state-dependent price reviews.

${ }^{7}$ A notable exception is the study by Fabiani et al. (2006) summarizing Euro area evidence on the patterns underlying price setting and reviewing. For the corresponding results for Germany see Stahl (2010). I comment in the next section on how these studies differs from my approach.
} 


\section{Related Empirical Literature}

Within the empirical literature analyzing the relative importance of time- versus state-dependence, there are three main approaches. The first approach, initiated by the seminal contribution of Cecchetti (1986) using data on magazine prices, is to analyze individual price records. More recent studies make use of large sets of price data on a broad range of goods collected by national statistical offices to calculate the Consumer-/ Producer Price Index (CPI/PPI). Overall, however, results from these studies concerning the price adjustment process remain rather inconclusive. For the U.S., Klenow and Kryvtsov (2008) find that neither time- nor classical state-dependent frameworks are consistent with micro data features. They suggest that, instead, models incorporating real rigidities such as economies of scope (Midrigan, 2007) or a Poisson distribution of idiosyncratic shocks (Gertler and Leahy, 2008), are better able to reflect the size and frequency of price changes observed in the data. Nakamura and Steinsson (2008a) find evidence for the importance of state-dependence as the frequency of price changes strongly reacts to inflation. A recent paper by Eichenbaum et al. (2010) stresses the importance of costs for the adjustment of "reference prices" using price data from a large U.S. retailer thus providing evidence for state-dependent pricing. For Belgian CPI data, Aucremanne and Dhyne (2005) show that while time-dependent factors are most important for price setting, state-dependent variables such as the rate of inflation, accumulated since the last price change, are significant as well. Furthermore, Dhyne et al. (2006) and Vermeulen et al. (2007), summarizing empirical findings of the Inflation Persistence Network (IPN) using CPI and PPI data respectively, find support for both time- and state-dependent elements for the Euro area. Corresponding studies for Germany include Stahl (2010) for producer prices and Hoffmann and Kurz-Kim (2006) for consumer prices.

A second stream of literature makes use of one-time firm-surveys asking firms explicitly for the timing of and reasons for price adjustment. Seminal work by Blinder (1991) for the U.S. has been followed by interview studies on European firms conducted by the IPN and summarized by Fabiani et al. (2006). The latter study finds that the majority of firms in the Euro area adjust prices taking into account state-dependent elements. For Germany, Stahl (2010) analyzes the results from such a one-time survey conducted by the Ifo institute for the manufacturing sector. A final approach has been to use business survey data on prices and other firm-specific variables. Lein (2010), using survey data of Swiss manufacturing firms, documents evidence for the importance of factors affecting the firm-specific environment, and in particular those related to production costs, for the timing of price adjustment. Moreover, for France Loupias and Sevestre (2010) finds evidence for the importance of intermediate input and labor costs as well as sectoral inflation for price setting in manufacturing. For the retail sector, such a business survey analysis has so far not been forthcoming. All in all, while the above-mentioned studies contain some evidence in favour of state-contingent price setting, they lack a thorough empirical assessment of the mechanism underlying the price updating. One exception is the 
study by Fabiani et al. (2006) that also contains evidence on patterns underlying price reviews in the Euro area. One result from this Euro area study is that, similar as for realized price changes, about two thirds of all firms apply state-dependent strategies when reviewing their prices. Corresponding results for Germany are presented in Stahl (2010); according to the onetime survey conducted by the Ifo institute about $40 \%$ of German manufacturing firms report to review their prices following time-dependent rules only. Relative to this interview approach the business survey dataset not only allows a deeper analysis of the different factors underlying price updating but also a more indirect assessment, which might mitigate measure measurement error.

As far as the transmission of price shocks through the production chain is concerned, theoretical models including an explicit production structure suggest that price stickiness "adds up" through the chain of processing (Blanchard, 1983; Basu, 1995; Huang and Liu, 2001; Nakamura and Steinsson, 2008b). So far, empirical evidence on these models' implications are rather mixed. Clark (1999) estimates a VAR model for the U.S. to analyze the effects of a monetary shock on prices set by firms across different stages of production and finds that input prices move much faster in response to a monetary shock than output prices at early stages of processing. The difference between input and output prices shrinks for subsequent stages suggesting that the retail sector does not add additional stickiness but that price rigidity rather accumulates. On the other hand, Nakamura (2008) studies the comovement of prices across products and firms using detailed U.S. price data and finds some evidence for retail firms playing the dominant role in the timing of price adjustment as retail-level shocks seem to drive a wedge between the observed price level and costs at the wholesale level.

\section{Empirical Strategy}

\subsection{Description and Discussion of the Business Survey Dataset}

The dataset consists of a large panel of business surveys for the retail sector conducted by the Ifo Institute for Economic Research. ${ }^{8}$ A summary of the variables used is given in Table 1. The econometric sample constructed from this dataset covers about 930 retail firms. Because some of the firms responded to several questionnaires for different product groups, the observation unit is firm-products leading to a total of 2,017 observation units. The sample runs from January 1991 to January $2006 . .^{9}$ As firms take part in the survey on a voluntary basis, not every firm responded every month resulting in an unbalanced dataset. To obtain a workable sample, I

\footnotetext{
${ }^{8}$ For more details on the survey data, see Appendix A and Becker and Wohlrabe (2008).

${ }^{9}$ Even though the micro survey data is available from 1990:01 the econometric sample constructed from the data starts in 1991:01 since the data for the sector-specific rate of inflation is not available prior to this date. Moreover, the sample only includes observations up to 2006:01 to avoid a break due to a significant change of the questionnaires afterwards.
} 
drop observation units with fewer than six data points. Because at the observation unit level the time elapsed since the last price adjustment is unknown before the first price change the data has been left-censored by dropping all observation units prior to the first price change for the respective firms. Moreover, in order to be able to correctly calculate the cumulative changes in the macroeconomic variables since the last price adjustment observations following (preceding) the missing observations are dropped until the next (previous) price change. ${ }^{10}$ After these manipulations the sample contains a total of about 78,000 observations. Each retail firm can be allocated to one of the following sectors according to the 4-digit WZ08 classification of the Federal Bureau of Statistics: Automobile, Food and Beverages, Communication and Information Technology, Household Products, Recreational Products, Other Industrial Products and Products not in Store. Thus, the composition of the products is similar to that of the consumer price index. Missing items relative to the CPI are services including housing rents as well as Energy goods such as oil products as well as gas and electricity.

Table 1: Dependent and Independent Variables

\begin{tabular}{|c|c|}
\hline Dependent variable & \\
\hline $\begin{array}{l}\text { prvpm } \\
\text { exppr }\end{array}$ & $\begin{array}{l}\text { price versus previous month } \\
\text { price expectation for coming three months }\end{array}$ \\
\hline \multicolumn{2}{|l|}{ Firm-specific variables } \\
\hline $\begin{array}{l}\text { busvol } \\
\text { statebus } \\
\text { ords } \\
\text { busdev }\end{array}$ & $\begin{array}{l}\text { business volume versus previous month } \\
\text { state of business (appraisal) } \\
\text { orders versus previous year (expectation) } \\
\text { business development (expectation) }\end{array}$ \\
\hline \multicolumn{2}{|c|}{ Wholesale/manufacturing prices } \\
\hline $\begin{array}{l}\text { pr_ws } \\
\text { pr_m }\end{array}$ & $\begin{array}{l}\text { net price incr. in wholesale (sector-specific) } \\
\text { net price incr. in manufact. (weighted average) }\end{array}$ \\
\hline \multicolumn{2}{|c|}{ Macroeconomic variables } \\
\hline $\begin{array}{l}\text { inflation } \\
\text { exchrate } \\
\text { oil }\end{array}$ & $\begin{array}{l}\text { cumulative sectoral rate of inflation } \\
\text { cumulative change in Euro/USD exchange rate } \\
\text { cumulative change in the oil price }\end{array}$ \\
\hline \multicolumn{2}{|l|}{ Institutional dummies } \\
\hline $\begin{array}{l}\text { Euro } \\
\text { vat }\end{array}$ & $\begin{array}{l}\text { introduction of Euro (+/- } 3 \text { months }) \\
\text { change in vat rate }(+/-3 \text { months })\end{array}$ \\
\hline \multicolumn{2}{|c|}{ "Time-dependent" variables } \\
\hline $\begin{array}{l}\text { taylor_j } \\
\text { winter/summer/fall }\end{array}$ & $\begin{array}{l}\text { Taylor dummy - price change } \mathrm{j} \text { months ago } \\
\text { seasonal dummies }\end{array}$ \\
\hline
\end{tabular}

Amongst other questions, firms are asked whether they changed the price of their products in the last month (denoted prvpm $_{i t}$ for firm $i$ in period $t$ ). The answers are coded as 1 ("increased"), 0 ("not changed") and -1 ("decreased"). Moreover, firms are asked whether they expect to change

\footnotetext{
${ }^{10}$ Results are robust to only dropping the observations following the missing data point until the next price change. Moreover, the main results still hold if missing observations are replaced by 0 . This implies the assumption that firms did in fact not change their price in the months they did not report. While this assumption seems reasonable for a dataset that is dominated by observation 0 for the price variable, it is of course rather strong.
} 
their prices in the coming three months; possible answers are again "increase", "decrease" and "no changes". Further questions considered in the analysis include variables concerning the state of the firm. For instance, firms are asked how they appraise the current state of business $\left(\right.$ statebus $\left._{i t}\right)$. Moreover, there are questions related to their business volume $\left(\right.$ busvol $\left._{i t}\right)$ versus the previous month as well as their expectations concerning their orders for the next three months relative to the same month in the previous year $\left(\operatorname{order} s_{i t}\right)$. Finally, firms are asked about their

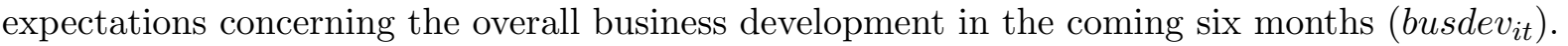

Relative to other datasets, the survey dataset provides several advantages. First, the business surveys contain information on price changes of every individual firm and, at the same time, on a range of different firm-specific variables. While quantitative price data underlying the CPI give precise results on the frequency and size of price changes, it is hard to disentangle which particular factors explain price setting because the individual price data cannot be matched with firm-specific variables. Second, the business survey data contain information on firms' price expectations allowing to analyze the price reviewing process, which is not possible using item-level price data. Third, the dataset allows to thoroughly analyze the effects of changes in the input prices on the probability of price adjustment for the respective stages of production. Such an assessment has not been forthcoming within the previous literature. A fourth advantage of the data is that firms are not asked directly on their pricing strategies as in one-time interview studies conducted by, for instance, Blinder (1991) for the U.S. and Fabiani et al. (2006), for the Euro area. Such an interview method may lead to biased responses as firms might be unwilling to respond truthfully to questions regarding their pricing strategies. Moreover, in contrast to the one-time interviews firms are asked every month, which better reveals their pricing behaviour over time. Despite these advantages it should be kept in mind that due to the qualitative nature of the questionnaires the data does not allow to make an inference concerning the size of price changes. ${ }^{11}$ Thus, all price changes are implicitly assumed to be equally sized in this analysis. A further limitation is that the survey data contains both single- and multi-product firms without providing any information on how the latter firms answer the question concerning their prices. This problem is mitigated by the fact that firms are asked to fill in different questionnaires for their respective product groups. Nevertheless, firms still have to cluster the price development of several sub-products within the same category resulting in a certain degree of aggregation of individual prices. However, a recent meta-study on the survey provides some details on how multi-product firms tend to fill in the questionnaires; in particular, the study reports that approximately half of the firms indicate the average price development of all of their products, while the other half report prices of their most important commodities. ${ }^{12}$

\footnotetext{
${ }^{11}$ However, constructing an aggregate time series from the micro data shows that the price data quite closely reflects movements in the official aggregate price indices. Figure B5 in Appendix B displays the comovement of the aggregated net price increase calculated from the survey data with the official German retail price index constructed by the Federal Bureau of Statistics. Moreover, more disaggregated time series for the respective sectors clearly comove with the official indices, as shown in Figure B6 in the Appendix.

${ }^{12}$ See Appendix A for more details.
} 


\subsection{Descriptive Statistics}

Table 2 shows the conditional and unconditional probabilities of observing a price change as well as a change in expectations of future prices, respectively. The conditional probabilities can be written as

$$
\begin{aligned}
p_{i j}(P) & =\operatorname{Prob}\left(P_{t}=i \mid x_{t}=j\right) \\
p_{i j}(E[P]) & =\operatorname{Prob}\left(E_{t}\left[P_{t+k}\right]=i \mid x_{t}=j\right),
\end{aligned}
$$

with $i \in(-1,0,1)$ and $j \in(-1,0,1)$. $P_{t}$ denotes the reported price realization in a given month, while $E_{t}\left[P_{t+k}\right]$ indicates the reported change in price expectations. Since firms report their price expectations for the coming three months, $k \in(1,2,3)$. $x_{t}$ denotes the realization of the respective firm-characteristic in the same month. First, the table reveals that price increases are somewhat more likely than price decreases; the unconditional probabilities of observing a price increase and decrease are $26.3 \%$ and $22.4 \%$, respectively, which is not surprising given a positive inflation environment. For price expectations this asymmetry between increases and decreases is more pronounced $(31.7 \%$ versus $14.6 \%)$. Second, the table shows the respective probabilities conditional on observing changes in the other firm-specific variables introduced above. In most of the cases improvements in the variables describing the state of the firm lead to a higher probability of observing a price increase compared to the probability of a price decrease, while in the case of deteriorations of the firm-specific factors, the probability of a price decrease is higher. This pattern is to be expected if the firm-specific situation depends positively on the demand situation facing the firm. ${ }^{13}$ For instance, the probability of observing both an improvement in the perceived state of business and a price increase is more than twice as large as that of a "good" state of business and a price decrease ( $5.2 \%$ versus $2 \%)$. Similarly, a price decrease is more likely than a price increase if the state of business is "bad" (13.2\% versus 8.6\%). A similar pattern can be observed for most of the other variables. In the case of a decreased business volume, the probability of a price increase is higher than that of a price decrease; the observation that both increases and decreases in the business volume lead to a higher chance of observing a price increase is somewhat surprising. This observation suggest that the effects of improvements on the one hand and deteriorations in the state of business on the other hand may sometimes be driven by different underlying mechanisms. These asymmetries should be accounted for in the empirical analysis. Conditional probabilities show a largely similar pattern for price expectations. As for price realizations, the respective probabilities of a price increase and decrease conditional on observing a decrease in the business volume are somewhat surprising. Moreover, in the cases of deteriorations in the state of business and in orders, respectively, price increases are slightly more likely than price decreases. However, the difference is rather small. All the other conditional probabilities are in line with the expected pattern.

\footnotetext{
${ }^{13}$ However, it is of course not clear ex ante whether considerations related to the demand situation on the one hand or supply-side factors on the other hand are dominant when firms answer questions related to their specific state of business.
} 
Table 3 offers some insights on the correlation between realized price changes and price expectations reporting the probability of observing a price change conditional on changes in expectations of future prices. As the upper panel of the table shows, there is a clear positive relation between the two variables; conditional on observing an increase in the expected future price, the probability of a realized price increase is highest (16.5\% versus $11.1 \%$ and $4.1 \%$ for observing no price change and a price decrease, respectively). Similarly, the combination of a decrease in both price realizations and expectations is much more likely than observing both a decrease in expected prices and an increase in the realized price (9.0\% versus $1.0 \%)$. The lower three panels of Table 3 show the probabilities of observing a price change conditional on lags of price expectations. Since firms are asked to report their expectations concerning the coming three months, probabilities for lags one, two and three are reported. The conditional probabilities reported in the table suggest that in most cases, firms act as previously expected. Conditional on having expected a price increase, the probabilities of actually observing a realized price increase one, two and three periods later are highest $(17.2 \%, 16.0 \%$ and $14.9 \%$, respectively). A similar pattern can be observed for expected price decreases. This suggests that changes in price expectations can indeed be interpreted as the setting of price plans by firms.

Table 2: Conditional and Unconditional Probabilities

\begin{tabular}{ll|ccc|ccc} 
& & \multicolumn{3}{|c|}{$P_{t}$} & \multicolumn{3}{|c}{$E_{t}\left[P_{t+k}\right]$} \\
\hline \hline \multirow{2}{*}{ unconditional } & & 1 & 0 & -1 & 1 & 0 & -1 \\
\hline statebus & 0.263 & 0.514 & 0.224 & 0.317 & 0.537 & 0.146 \\
& good & 0.052 & 0.065 & 0.020 & 0.060 & 0.065 & 0.013 \\
& normal & 0.125 & 0.238 & 0.072 & 0.149 & 0.244 & 0.041 \\
& bad & 0.086 & 0.211 & 0.132 & 0.108 & 0.228 & 0.092 \\
\hline busvol & higher & 0.099 & 0.167 & 0.051 & 0.124 & 0.160 & 0.033 \\
& as high & 0.068 & 0.147 & 0.041 & 0.077 & 0.150 & 0.029 \\
& lower & 0.116 & 0.202 & 0.109 & 0.140 & 0.216 & 0.070 \\
\hline \multirow{2}{*}{ orders } & higher & 0.036 & 0.045 & 0.021 & 0.046 & 0.044 & 0.012 \\
& as high & 0.146 & 0.282 & 0.079 & 0.171 & 0.295 & 0.041 \\
& lower & 0.081 & 0.187 & 0.124 & 0.100 & 0.198 & 0.093 \\
\hline busdev & better & 0.042 & 0.058 & 0.027 & 0.052 & 0.060 & 0.015 \\
& as good & 0.154 & 0.308 & 0.094 & 0.182 & 0.327 & 0.047 \\
& worse & 0.066 & 0.148 & 0.103 & 0.083 & 0.150 & 0.084 \\
\hline \hline
\end{tabular}

The left panel of the table presents the conditional and unconditional probabilities of observing a price increase (1), decrease (-1) and no price change (0). The right panel reports the corresponding probabilities for observing an increase (1), decrease $(-1)$ or no change $(0)$ in price expectations for the coming three months. Since firms report expectations for the coming three months, $k \in(1,2,3)$. The sample period is 1991:01-2006:01. 
Table 3: Conditional Probabilities of Price Change Given Price Expectations

\begin{tabular}{ll|ccc} 
& & \multicolumn{3}{|c}{$P_{t}$} \\
\hline \hline$E_{t}\left[P_{t+k}\right]$ & Increase & 0.165 & 0.111 & 0.041 \\
& No change & 0.088 & 0.356 & 0.093 \\
& Decrease & 0.010 & 0.047 & 0.090 \\
\hline$E_{t-1}\left[P_{t-1+k}\right]$ & Increase & 0.172 & 0.118 & 0.023 \\
& No change & 0.066 & 0.393 & 0.084 \\
& Decrease & 0.007 & 0.041 & 0.097 \\
\hline$E_{t-2}\left[P_{t-2+k}\right]$ & Increase & 0.160 & 0.126 & 0.022 \\
& No change & 0.067 & 0.397 & 0.088 \\
& Decrease & 0.011 & 0.040 & 0.089 \\
\hline$E_{t-3}\left[P_{t-3+k}\right]$ & Increase & 0.149 & 0.134 & 0.025 \\
& No change & 0.072 & 0.381 & 0.100 \\
& Decrease & 0.017 & 0.045 & 0.077 \\
\hline \hline
\end{tabular}

The table presents the probabilities of observing a price increase (1), decrease (-1) and no price change (0) conditional on price expectations in a given month as well as one, two and three months ago, respectively. Since firms report expectations for the coming three months, $k \in(1,2,3)$. The sample period is 1991:01-2006:01.

Finally, Figure 1 provides some aggregated statistics calculated from the micro data. The upper panel of the figure plots the frequency of price changes calculated from the business survey data as well as the rate of retail price inflation. The figure reveals that the frequency of price adjustment is not completely stable but seems to comove with the rate of inflation over time. The lower panel of the figure displays the frequency of price increases and decreases, respectively, as well as the rate of retail price inflation. The figure clearly shows the comovement between the rate of inflation and the frequency of price increases. Thus, both figures suggest that the frequency of price changes is not invariant over time as predicted by time-dependent theories but that it seems to depend on the overall inflation environment. 


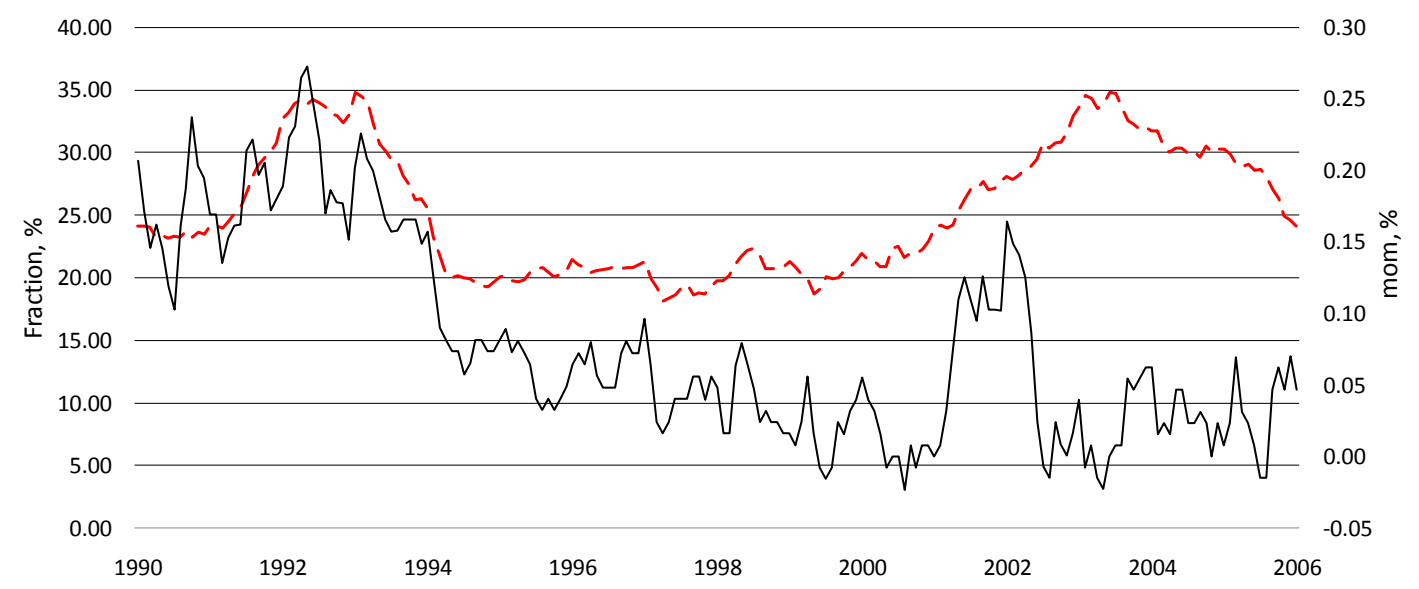

- Fraction of price changes (left scale) — Retail price inflation (right scale)

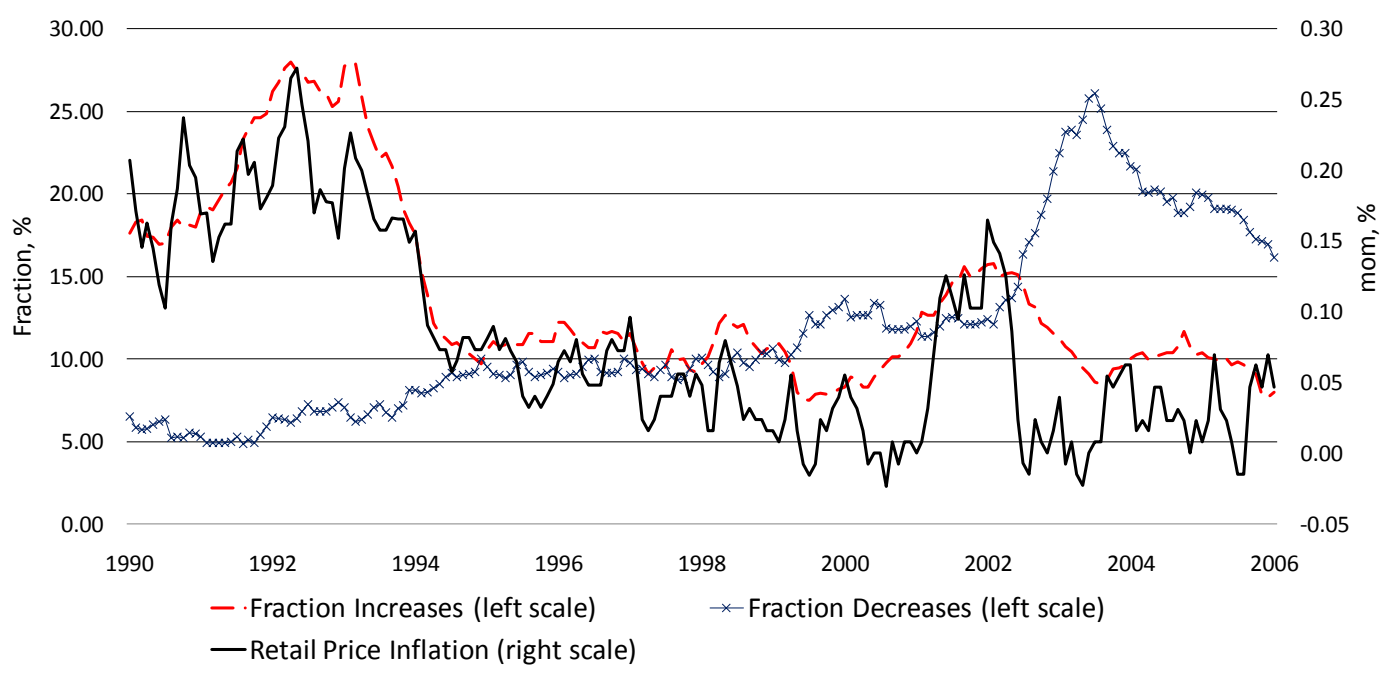

Figure 1: Frequency of Price Changes and Retail Price Inflation

Both figures display year-on-year changes of the retail price index. The frequency of price changes as well as the frequency of price increases and decreases enter as 12-month moving averages. 


\subsection{Econometric Model}

The dependent price variables prvpm $_{i t}$ and exppr $_{i t}$ have three discrete outcomes: -1 for a price decrease (expected price decrease), 0 if there is no price change (if no price change is expected) and +1 for a price increase (expected price increase). A latent variable specification is assumed to underly the data generating process with an unobserved quantitative price variable $y_{i t}^{*}$ depending on a set of explanatory variables:

$$
y_{i t}^{*}=\mathbf{x}_{\mathbf{i t}}^{\prime} \boldsymbol{\beta}+u_{i t} .
$$

Following the target-threshold approach suggested by Cecchetti (1986) a menu cost interpretation is applied to this specification. In particular, a fixed cost of price adjustment is assumed that prevents firms from changing prices every period. To derive an econometric specification I assume the following observation rule for the observed discrete price variable $y_{i t}$ :

$$
y_{i t}=\left\{\begin{aligned}
-1 & \text { if } y_{i t}^{*} \leq \alpha_{1} \\
0 & \text { if } \alpha_{1} \leq y_{i t}^{*} \leq \alpha_{2} \\
1 & \text { if } \alpha_{2}<y_{i t}^{*}
\end{aligned}\right.
$$

where $\alpha_{1}$ and $\alpha_{2}$ are thresholds assumed to be invariant across time and units of observation. Thus, according to this model, the price is increased as soon as the latent price variable $y_{i t}^{*}$ exceeds threshold $\alpha_{2}$, the price is decreased if $y_{i t}^{*}$ is below threshold $\alpha_{1}$ and the price remains unchanged if the unobserved price variable stays within the cutoff-points. The model is estimated by means of an ordered probit specification. Since the latent variable can be interpreted as deviation of the actual price from the desired optimal price, this ordinal interpretation of the dependent variable applies here. ${ }^{14}$ For instance, a high sectoral rate of inflation implies that the realized price is likely to be below the optimal price. Thus, adjustment decision 1 (price increase) is preferred to 0 (no price change), which in turn is preferred to -1 (price decrease). ${ }^{15}$

Additionally, a bivariate specification is estimated in order to control for a possible correlation between the process of price setting and price updating. Arguably, a firm's decision to change its price depends on it's expectations of the future price development. A specification that controls for this correlation leads to a more efficient estimation (Cameron and Trivedi, 2007). In particular, since both dependent variables have three outcome possibilities, a bivariate ordered probit model is estimated. The probability model can be derived from the following latent variable specification:

\footnotetext{
${ }^{14}$ Furthermore, the difference between the thresholds can be interpreted to relate to a menu cost; the higher the fixed cost of changing the price, the larger is the difference between the cutoff-points and the underlying latent variable has to take on more extreme values in order for a price change to occur.

${ }^{15}$ However, to account for possible asymmetries between price increases and decreases, respectively, I additionally estimate the model separately for these respective outcomes using a conditional logit specification. Results are given in Section 4.5.
} 


$$
\begin{aligned}
& y_{1 i t}^{*}=\mathbf{x}_{1 \mathbf{i t}}^{\prime} \boldsymbol{\beta}_{\mathbf{1}}+\epsilon_{1 i t} \\
& y_{2 i t}^{*}=\mathbf{x}_{\mathbf{2 i t}}^{\prime} \boldsymbol{\beta}_{\mathbf{2}}+\gamma y_{1 i t}^{*}+\epsilon_{2 i t},
\end{aligned}
$$

where $\beta_{1}$ and $\beta_{2}$ are vectors of unknown parameters and $\gamma$ is an unknown scalar. $\epsilon_{1 i}$ and $\epsilon_{2 i}$ are error terms that are assumed to be distributed as bivariate standard normal with correlation $\rho$ (Sajaia, 2008). The observation rules for the dependent variables $y_{1 i t}$ and $y_{2 i t}$ are analogous to equation (2).

Both models are estimated without the explicit inclusion of individual-specific effects. First, to account for observable heterogeneity, sector-specific dummy variables are included to the set of regressors. Moreover, due to the firm-specific nature of the dataset at hand, arguably, a large extent of firm heterogeneity is already captured by some of the regressors (Lein, 2010). To mitigate the remaining problem of unobserved heterogeneity, I employ the Mundlak-Chamberlain approach of correlated random effects and assume the latent variable specification to take on the following form: $y_{j i t}^{*}=\mathbf{x}_{\mathbf{j i t}} \boldsymbol{\beta}_{\boldsymbol{j}}+\alpha_{i}+u_{j i t}$, where $j=(1,2)$ indicates the respective dependent variable and $\alpha_{i}$ are unobserved individual-specific effects. Following e.g. Mundlak (1978), $\alpha_{i}$ is assumed to be related to observed characteristics in the model according to: $\alpha_{i}=\bar{x}_{j i}^{\prime} a+\zeta_{i}$, where $\zeta_{i} \sim$ iid Normal and independent of $x_{j i t}$ and $u_{j i t}$. To implement this approach, a vector of firm-specific means of the individual-specific variables is added to the set of regressors.

\subsection{Price Setting Equations}

Following, for instance, Aucremanne and Dhyne (2005), $\mathbf{x}_{\mathbf{i}}^{\prime} \boldsymbol{\beta}$ in equation (1) represents a mix of time- and state-dependent variables. For the empirical analysis of price setting, the following four specifications are estimated:

$$
\begin{aligned}
& y_{i t}^{*}(1)=\beta_{1} I_{i t}+\beta_{2} D_{i t}^{s}+\beta_{3} D_{i t}^{t}+u_{i t} \\
& y_{i t}^{*}(2)=\beta_{1} I_{i t}+\beta_{2} M a c_{i t}+\beta_{3} D_{i t}^{s}+\beta_{4} D_{i t}^{t}+\beta_{5} D_{i t}^{i}+u_{i t} \\
& y_{i t}^{*}(3)=\beta_{1} I_{i t}+\beta_{2} M a c_{i t}+\beta_{3} P_{i t}+\beta_{4} D_{i t}^{s}+\beta_{5} D_{i t}^{t}+\beta_{6} D_{i t}^{i}+u_{i t} \\
& y_{i t}^{*}(4)=\beta_{1} I_{i t}+\beta_{2} M a c_{i t}+\beta_{3} P_{i t}+\beta_{4} l P_{i t}+\beta_{5} D_{i t}^{s}+\beta_{6} D_{i t}^{t}+\beta_{7} D_{i t}^{i}+u_{i t} .
\end{aligned}
$$

Estimating specification (1) it will be analyzed whether next to time dependent variables measures reflecting the state of the firm have a significant effect on the probability of price adjustment. $I_{i t}$ denotes a vector of the firm-specific variables described in the previous section. Because the descriptive evidence explained above points to asymmetric effects of improvements and deteriorations in the respective variables, two different dummies are constructed of all of 
them. ${ }^{16}$ The first dummy, labeled ${ }^{+}$, equals 1 if there is an increase or if the situation is good, respectively, and 0 otherwise. The second dummy, labeled ${ }^{-}$, equals 1 if there is a decrease or if the situation is bad and 0 otherwise. Furthermore, a set of time-dependent variables, indicated by $D_{i t}^{t}$, is added to the specification. To investigate whether firms in the dataset employ Taylortype pricing, Taylor dummies are constructed indicating that the last price change occurred a fixed period ago. Studies on the frequency of price changes as, for instance, Hoffmann and KurzKim (2006) for Germany show that there are spikes in hazard rates at six, 12, 18 and 24 months. Therefore, dummy variables are defined accordingly as Taylor $6_{i t}$, Taylor $12_{i t}$, Taylor $18_{i t}$ and Taylor $24_{i t}$. Furthermore, seasonal dummies are constructed to examine whether the probability of repricing according to fixed time intervals is increased. As is often stressed in the empirical literature on price setting, a large degree of heterogeneity is observed both between and within product groups. Observable differences between sectors are accounted for by including sectorspecific dummy variables, indicated by $D_{i t}^{s}$. As explained before, a vector $M_{i t}$ of firm-specific averages of the individual-specific variables is added to account for unobserved heterogeneity.

To analyze the importance of the aggregate state of the economy for price setting, a vector of macroeconomic variables, indicated by $M a c_{i t}$, is included in the set of regressors. In standard menu cost models the likelihood of price adjustment depends on the distance of the actual to the optimal price. Because the optimal price itself varies with the state of the economy, this distance depends on changes in macroeconomic factors, accumulated since the last price change. Hence, cumulative values of all macroeconomic variables since the last price adjustment are considered. ${ }^{17}$ Furthermore, a set of dummy variables, $D_{i t}^{i}$, controlling for important institutional events is added. This leads to the augmented specification (2). According to, for instance, Dotsey et al. (1999), an increase in inflation leads to a decline in relative prices of individual firms which should increase the probability of repricing. Thus, the cumulative sectoral rates of inflation since the last price change are included as regressors. ${ }^{18}$ Furthermore, a measure of cumulative changes in the oil price is included to account for changes in raw material costs related to global demand or supply shocks. Moreover, the cumulative Euro/USD exchange rate is added to capture changes in foreign demand. The vector of macroeconomic variables can thus be characterized by the following expression: $M a c_{i t}=\left[\Delta^{\text {cum }} P_{i t}^{j}, \Delta^{c u m} P_{i t}^{o i l}, \Delta^{c u m} E_{i t}^{\in / \$}\right]^{\prime}$, where $P_{i t}^{j}$ indicates the price level for sector $j, P_{i t}^{o i l}$ is the oil price and $E_{i t}^{\epsilon / \$}$ stands for the Euro/USD

\footnotetext{
${ }^{16}$ Endogeneity does not seem to be a problem when using the firm-specific variables as regressors; results are robust to including these variables in first lags as well as to using an instrumental variables estimation. See Section 4.5 for details.

${ }^{17}$ Card and Sullivan (1988) show that cumulative variables may lead to endogeneity issues and thus to biased estimators because they can be expressed as $x_{i t}=1+\left(1-y_{i t-1}\right) x_{i t-1}$. Thus, to account for possible endogeneity problems associated with these variables the model is additionally estimated by including the first individual observation of the dependent variable as an additional regressor, as has been suggested by Wooldridge (2005) and applied by Loupias and Sevestre (2010). Results, which are available upon request, are robust to this modification.

${ }^{18}$ The inflation rates for the six respective retail sectors are obtained from the Federal Bureau of Statistics and are matched with the survey data according to the WZ08 classification. I include values that are lagged by one period to avoid possible endogeneity problem that may result at this degree of disaggregation. As shown in the subsection on robustness checks, results are similar if the cumulative rate of consumer price inflation rate is used instead of the measures of sectoral inflation.
} 
exchange rate. ${ }^{19}$ Furthermore, a set of dummies reflecting important institutional events $\left(D_{i t}^{i}\right)$ is added to the price setting equation. Events that might influence the decision to adjust prices are the introduction of the Euro in 2002 as well as the increases in the value added tax in 1993 and 1998. The dummies take on the value 1 in the month of the change as well as in the previous and following three months.

In order to shed more light on how price shocks are transmitted through the chain of production, variables measuring changes in input prices are included in the specification. Moreover, adding lags of these variables allows to analyze the length of the adjustment process to input price changes. In specifications (3) and (4) $P_{i t}$ indicates a vector of input price variables. Both wholesale and manufacturing price developments are considered, because retail firms use products of both sectors as inputs. ${ }^{20}$ For the construction of the input price measure, business survey data for the wholesale and manufacturing sector is used. Within these sectors, firms are asked similar questions regarding their price development as compared to the retail sector. ${ }^{21}$ As far as data for the wholesale sector is concerned, as both datasets are classified according to the same internal classification scheme of the Ifo institute, wholesale price data could exactly be matched to the retail data on a product group-specific basis ${ }^{22}$ The frequency of net price increases in the wholesale sector was calculated as an average of all firms of a particular three-digit product category for every month in every year. Thus, for every product category, the frequency of net price increases was constructed according to:

$$
F_{j t}^{w s,+}=\frac{\sum_{i=1}^{n_{j}} y_{i j t}^{w s,+}-\sum_{i=1}^{n_{j}} y_{i j t}^{w s,-}}{\sum_{i=1}^{n_{j}} y_{i j t}^{w s,+}+\sum_{i=1}^{n_{j}} y_{i j t}^{w s,-}+\sum_{i=1}^{n_{j}} y_{i j t}^{w s, 0}},
$$

where $F_{j t}^{w s,+}$ denotes the frequency of net price increases of a particular product-group $j$ within the wholesale sector, $y_{i j t}^{w s,+}$ and $y_{i j t}^{w s,-}$ indicate a price increase and a price decrease of firm i belonging to sector $\mathrm{j}$ at time $\mathrm{t}$, respectively, and $y_{i j t}^{w s, 0}$ indicates that the price was not changed. These "time series" for the different product groups could then be matched to every retail firm belonging to the same category. Such an exact match was possible for about $67 \%$ of the retail firms. For manufacturing prices, unfortunately, a sector-specific match of input prices was not possible because this dataset has been coded differently. To construct a measure of the price development, therefore, a weighted average of net price increases of all sectors was constructed

\footnotetext{
${ }^{19}$ Arguably, this set of macroeconomic variables only constitutes a certain selection of relevant factors and may not cover the entire macroeconomic environment facing the firms. To take account of this possibility I additionally estimate specification (2) including time-specific effects instead of the vector $M a c_{i t}$. More details and regression results are presented in Section 4.5.

${ }^{20}$ Because according to the input-output table of the Federal Bureau of Statistics retail products make up for only about $1 \%$ of all inputs used by the wholesale sector, assuming the wholesale price variable to be exogenous in the retail price equation seems reasonable.

${ }^{21}$ See Becker and Wohlrabe (2008).

${ }^{22}$ According to the internal Ifo classification scheme, the term "product group" implies an ordering according to the first three digits of the five-digit product code.
} 
for every time unit: $F_{t}^{m,+}=\sum_{j=1}^{J} \omega_{j} F_{j t}^{m,+} . F_{j t}^{w s,+}$ denotes the weighted average of net price increases within the manufacturing sector and $F_{j t}^{m,+}$ indicates the frequency of net price increases within each particular manufacturing sector. $\omega_{j}$ indicates the respective weight for each sector. ${ }^{23}$

\section{Results}

\subsection{Time-vs. State-Dependence}

Results for the baseline price setting equation (1), the specification including aggregate variables (2) as well as the equation adding intermediate input costs (3) are shown in Table 4. The table reports marginal effects for the outcomes 1 (price increase) and -1 (price decrease) as well as robust standard errors. First, in specification (1) all time-dependent variables have significant effects on the probability of price adjustment. For instance, a firm that raised it's price exactly four quarters ago faces a $1 \%$ higher probability of a price increase in a given period. $^{24}$ Furthermore, all seasonal dummies are significant. For example, compared to the benchmark season spring, a price increase is $3.6 \%$ more likely during winter and $2.4 \%$ less likely during summer. Next to the time-dependent variables, most of the firm-specific measures show highly significant effects and have the expected signs. A decrease in the state of business decreases the probability of observing a price increase by $6.5 \%$, while it increases the likelihood of a price decrease by $6.2 \%$. Similarly, decreases in the expected business development and in orders decrease (increase) the probability of a price increase (decrease). Moreover, as expected, improvements in the state of business and increases in the business volume increase (decrease) the likelihood of a price increase (decrease); marginal effects are similar as compared to decreases in the firm-specific variables ranging from $3.2 \%$ to $5.4 \%$. However, the direction of the effect of a decrease in business volume is rather surprising leading to a higher likelihood of a price increase (and vice versa). Nevertheless, this result is in line with the descriptive evidence on the conditional probabilities explained in the last section reporting a higher probability of a price increase compared to a decrease conditional on observing a lower business volume. This implies that this surprising result is indeed driven by the data and not by the econometric model employed. Moreover, the signs of the marginal effects for increases in orders and improvements in the expected business development are surprising; however, the effect of the former dummy is insignificant, while the marginal effect of the latter is rather small. Overall, the statistically and economically significant effects of the firm-specific variables leads to the tentative conclusion that state-dependence is important for the pricing behaviour of German retail firms.

Adding the cumulative macroeconomic variables as well as the institutional dummies (columns four and five in Table 4) further reinforces the evidence in favour of state-dependence. The

\footnotetext{
${ }^{23}$ The respective weights are chosen according to their respective usage within the retail sector given in the official input-output table of the Federal Bureau of Statistics.

${ }^{24}$ Taylor dummies indicating that the last price change was six and 18 months ago, respectively, are also significant but not shown in the table for reasons of space.
} 
effects of cumulative changes of the sectoral rates of inflation as well as the oil price are highly significant and show the expected signs. In particular, an increase in the sector-specific rate of inflation, accumulated since the last price adjustment, by one percent raises the probability of a price increase by $2.7 \%$, while it reduces the chance of observing a price decrease by $2.5 \%$. Moreover, a unit increase in the cumulative change of the oil price leads to a higher (lower) likelihood of a price increase (decrease). Furthermore, a depreciation of the Euro/USD exchange rate increases the likelihood of observing a price increase, which is in line with economic theory since a lower value of the Euro may increase export demand. However, the effect is insignificant. Moreover, changes in the institutional environment are significantly related to the timing of price adjustment. More specifically, the dummy indicating increases in the VAT rate has a particularly high effect raising (lowering) the probability of a price increase (decrease) by $8.2 \%$ (6.4\%). Similarly, the introduction of the Euro led more firms to increase their prices, while the fraction of firms decreasing prices was significantly reduced. As can be seen in the table, the firm-specific variables are robust to the inclusion of the macroeconomic factors. Furthermore, while the time-dependent variables are generally still significant, the seasonal dummies show somewhat reduced marginal effects.

Columns six and seven of Table 4 show regression results of specification (3) that includes changes in intermediate input costs. Both measures are highly significant and have the expected effects. An increase in the measure of manufacturing prices by one unit increases the likelihood of a price increase by $4.5 \%$ and reduces the chance to observe a price decrease by $3.5 \%$. An increase in the sector-specific measure of wholesale prices is particularly effective leading even to a $32.8 \%$ higher and a $25.8 \%$ lower likelihood of a price increase and decrease, respectively. As before, firm-specific variables are robust to the inclusion of the intermediate input cost measures. While the Taylor dummies are robust, too, interestingly, the seasonal dummies are now insignificant. This suggests that in specifications (1) and (2) these variables capture part of the variations in intermediate input costs. Once these latter effects are controlled for, the importance of seasonal effects vanishes indicating that the seasonality observed after estimating specifications (1) and (2) is in fact not due to time-dependent pricing behaviour.

All in all, the results reported in Table 4 suggest that while elements such as Taylor pricing are relevant for the repricing probability of retail firms, a pure time-dependent representation of pricing is clearly rejected. Most of the factors characterizing both the firm-specific and aggregate state of the firms are highly significant and have economically important effects on the price adjustment decision. Moreover, seasonality is only present in the data as long as intermediate input costs are not accounted for. This finding reveals that empirical results reported in the literature might be misleading as long as the specification does not control for such statedependent factors.

\subsection{Intermediate Inputs}

Regression results of specification (3) show that intermediate input prices are generally important determinants for price adjustment of retail firms. In price setting equation (4) six lags of the 
respective input prices have been added to the specification in order to analyze the speed of price adjustment to input cost disturbances. Regression results are shown in Table 5. As far as the product group-specific "wholesale price index" is concerned, almost all lags are significant and have economically important effects. This suggests that on average, retail firms do not react immediately to a wholesale price change but that the adjustment process is only complete after several months. Adding up the marginal effects for the significant lags yields cumulative effects of a unit increase in the wholesale price measure on the probability of observing a price increase and decrease of $9.7 \%$ and $7.4 \%$, respectively. Similarly, adjustment to manufacturing price changes seems to be sluggish; all lags of the manufacturing price index are significant. The accumulated effect is about $6.9 \%$ and $9.1 \%$ for price increases and decreases, respectively.

Two main conclusions emerge from these estimation results. First, intermediate input prices are important determinants of price adjustment in retail. This suggests that in order to make realistic predictions concerning the price adjustment process and hence the effects of monetary policy on the real economy price setting theories should explicitly model the transmission of price changes through the production chain. This is done by, for instance, Basu (1995), Huang and Liu (2001) and Nakamura and Steinsson (2008b). Second, however, changes in input costs are not fully reflected in the repricing probability on impact. Instead, intermediate goods price changes have an effect on the price adjustment decision within the retail sector for several months following the change. This suggests that there is "additional rigidity" at the retail level, which is not in line with the predictions of the above-mentioned price setting models. Instead, these models imply that price stickiness "adds up" through the production chain and thus, at the last stage of processing, prices adjust immediately to cost changes at the preceding stage. By contrast, the regression results shown in Table 5 are in line with the empirical study by Nakamura (2008) showing that price stickiness at the retail level is dominant for the timing of retail price changes relative to the preceding production stages. 
Table 4: Ordered Probit Regressions I

\begin{tabular}{|c|c|c|c|c|c|c|}
\hline & \multicolumn{2}{|c|}{ (1) } & \multicolumn{2}{|c|}{$(2)$} & \multicolumn{2}{|c|}{ (3) } \\
\hline & Increases & Decreases & Increases & Decreases & Increases & Decreases \\
\hline statebus $^{-}$ & $\begin{array}{c}-0.065^{* * *} \\
(0.003)\end{array}$ & $\begin{array}{c}0.062^{* * *} \\
(0.003)\end{array}$ & $\begin{array}{c}-0.055^{* * *} \\
(0.003)\end{array}$ & $\begin{array}{c}0.052^{* * *} \\
(0.003)\end{array}$ & $\begin{array}{c}-0.031^{* * *} \\
(0.004)\end{array}$ & $\begin{array}{c}0.025^{* * *} \\
(0.003)\end{array}$ \\
\hline busvol $^{-}$ & $\begin{array}{c}0.024^{* * *} \\
(0.003)\end{array}$ & $\begin{array}{c}-0.022^{* * *} \\
(0.003)\end{array}$ & $\begin{array}{c}0.019^{* * *} \\
(0.003)\end{array}$ & $\begin{array}{c}-0.017^{* * *} \\
(0.003)\end{array}$ & $\begin{array}{l}-0.002 \\
(0.004)\end{array}$ & $\begin{array}{c}0.002 \\
(0.003)\end{array}$ \\
\hline orders $^{-}$ & $\begin{array}{c}-0.036^{* * *} \\
(0.003)\end{array}$ & $\begin{array}{c}0.034^{* * *} \\
(0.003)\end{array}$ & $\begin{array}{c}-0.033^{* * *} \\
(0.003)\end{array}$ & $\begin{array}{c}0.031^{* * *} \\
(0.003)\end{array}$ & $\begin{array}{c}-0.031^{* * *} \\
(0.004)\end{array}$ & $\begin{array}{c}0.025^{* * *} \\
(0.004)\end{array}$ \\
\hline busdev $^{-}$ & $\begin{array}{c}-0.027^{* * *} \\
(0.003)\end{array}$ & $\begin{array}{c}0.026^{* * *} \\
(0.003)\end{array}$ & $\begin{array}{c}-0.030 * * * \\
(0.003)\end{array}$ & $\begin{array}{c}0.029 * * * \\
(0.003)\end{array}$ & $\begin{array}{c}-0.034^{* * *} \\
(0.005)\end{array}$ & $\begin{array}{c}0.028^{* * *} \\
(0.004)\end{array}$ \\
\hline statebus $^{+}$ & $\begin{array}{c}0.037^{* * *} \\
(0.005)\end{array}$ & $\begin{array}{c}-0.032^{* * *} \\
(0.004)\end{array}$ & $\begin{array}{c}0.032^{* * *} \\
(0.005)\end{array}$ & $\begin{array}{c}-0.027^{* * *} \\
(0.004)\end{array}$ & $\begin{array}{c}0.013^{* *} \\
(0.006)\end{array}$ & $\begin{array}{c}-0.010^{* *} \\
(0.005)\end{array}$ \\
\hline busvol $^{+}$ & $\begin{array}{c}0.054^{* * *} \\
(0.003)\end{array}$ & $\begin{array}{c}-0.048^{* * *} \\
(0.003)\end{array}$ & $\begin{array}{c}0.049^{* * *} * \\
(0.004)\end{array}$ & $\begin{array}{c}-0.043^{* * *} \\
(0.003)\end{array}$ & $\begin{array}{c}0.039 * * * \\
(0.005)\end{array}$ & $\begin{array}{c}-0.030^{* * * *} \\
(0.003)\end{array}$ \\
\hline orders $^{+}$ & $\begin{array}{l}-0.005 \\
(0.006)\end{array}$ & $\begin{array}{c}0.004 \\
(0.006)\end{array}$ & $\begin{array}{l}-0.006 \\
(0.006)\end{array}$ & $\begin{array}{c}0.006 \\
(0.005)\end{array}$ & $\begin{array}{c}-0.031^{* * *} \\
(0.007)\end{array}$ & $\begin{array}{c}0.027^{* * *} \\
(0.007)\end{array}$ \\
\hline busdev $^{+}$ & $\begin{array}{c}-0.018^{* * *} \\
(0.005) \\
\end{array}$ & $\begin{array}{c}0.018^{* * *} \\
(0.005)\end{array}$ & $\begin{array}{c}-0.017^{* * *} \\
(0.005)\end{array}$ & $\begin{array}{c}0.017^{* * *} \\
(0.005)\end{array}$ & $\begin{array}{c}-0.037^{* * *} \\
(0.006)\end{array}$ & $\begin{array}{c}0.032^{* * *} \\
(0.006)\end{array}$ \\
\hline inflation & & & $\begin{array}{c}0.027^{* * *} \\
(0.004)\end{array}$ & $\begin{array}{c}-0.025^{* * *} \\
(0.003)\end{array}$ & $\begin{array}{c}0.018^{* * *} \\
(0.005)\end{array}$ & $\begin{array}{c}-0.014^{* * * *} \\
(0.004)\end{array}$ \\
\hline oil & & & $\begin{array}{c}0.053^{* * *} \\
(0.010)\end{array}$ & $\begin{array}{c}-0.049 * * * \\
(0.009)\end{array}$ & $\begin{array}{c}0.062^{* * *} \\
(0.013)\end{array}$ & $\begin{array}{c}-0.049^{* * *} \\
(0.011)\end{array}$ \\
\hline exchrate & & & $\begin{array}{c}0.012 \\
(0.014)\end{array}$ & $\begin{array}{c}-0.011 \\
(0.013)\end{array}$ & $\begin{array}{c}0.013 \\
(0.019)\end{array}$ & $\begin{array}{l}-0.010 \\
(0.015)\end{array}$ \\
\hline EUR & & & $\begin{array}{c}0.036^{* * *} \\
(0.007)\end{array}$ & $\begin{array}{c}-0.030 * * * \\
(0.006)\end{array}$ & $\begin{array}{c}0.037 * * * \\
(0.010)\end{array}$ & $\begin{array}{c}-0.027^{* * * *} \\
(0.006)\end{array}$ \\
\hline VAT & & & $\begin{array}{c}0.082^{* * *} \\
(0.005) \\
\end{array}$ & $\begin{array}{c}-0.064^{* * *} \\
(0.003) \\
\end{array}$ & $\begin{array}{c}0.079 * * * \\
(0.007)\end{array}$ & $\begin{array}{c}-0.053^{* * *} \\
(0.004) \\
\end{array}$ \\
\hline $\begin{array}{l}\text { pr_man } \\
\text { pr_ws }\end{array}$ & & & & & $\begin{array}{c}0.045^{* * *} \\
(0.007) \\
0.328^{* * *} \\
(0.007)\end{array}$ & $\begin{array}{c}-0.035^{* * *} \\
(0.005) \\
-0.258^{* * *} \\
(0.006)\end{array}$ \\
\hline taylor12 & $\begin{array}{c}0.010^{* * * *} \\
(0.003)\end{array}$ & $\begin{array}{c}-0.010^{* * *} \\
(0.003)\end{array}$ & $\begin{array}{c}0.014^{* * *} \\
(0.003)\end{array}$ & $\begin{array}{c}-0.013^{* * *} \\
(0.003)\end{array}$ & $\begin{array}{c}0.021 * * * \\
(0.004)\end{array}$ & $\begin{array}{c}-0.016^{* * * *} \\
(0.003)\end{array}$ \\
\hline taylor24 & $\begin{array}{c}-0.026^{* * *} \\
(0.003)\end{array}$ & $\begin{array}{c}0.025^{* * *} \\
(0.003)\end{array}$ & $\begin{array}{c}-0.025^{* * *} \\
(0.003)\end{array}$ & $\begin{array}{c}0.024^{* * *} \\
(0.003)\end{array}$ & $\begin{array}{c}-0.018^{* * *} \\
(0.004)\end{array}$ & $\begin{array}{c}0.014^{* * *} \\
(0.003)\end{array}$ \\
\hline winter & $\begin{array}{c}0.036^{* * *} \\
(0.004)\end{array}$ & $\begin{array}{c}-0.033^{* * *} \\
(0.003)\end{array}$ & $\begin{array}{c}0.021^{* * *} \\
(0.004)\end{array}$ & $\begin{array}{c}-0.019 * * * \\
(0.003)\end{array}$ & $\begin{array}{c}0.005 \\
(0.005)\end{array}$ & $\begin{array}{l}-0.004 \\
(0.004)\end{array}$ \\
\hline summer & $\begin{array}{c}-0.024 * * * \\
(0.003)\end{array}$ & $\begin{array}{c}0.023^{* * *} * \\
(0.003)\end{array}$ & $\begin{array}{c}-0.018^{* * *} \\
(0.003)\end{array}$ & $\begin{array}{c}0.017^{* * *} \\
(0.003)\end{array}$ & $\begin{array}{c}0.000 \\
(0.005)\end{array}$ & $\begin{array}{c}0.000 \\
(0.004)\end{array}$ \\
\hline fall & $\begin{array}{c}-0.033^{* * *} \\
(0.003) \\
\end{array}$ & $\begin{array}{c}0.032^{* * *} \\
(0.003) \\
\end{array}$ & $\begin{array}{c}-0.034^{* * *} \\
(0.003) \\
\end{array}$ & $\begin{array}{c}0.033^{* * *} \\
(0.003) \\
\end{array}$ & $\begin{array}{c}-0.006 \\
(0.005) \\
\end{array}$ & $\begin{array}{c}0.005 \\
(0.004) \\
\end{array}$ \\
\hline $\begin{array}{l}\text { Log-Lik. } \\
\text { Obs. } \\
\text { Ps.-R2 }\end{array}$ & $\begin{array}{c}-73529.83 \\
78073 \\
0.092\end{array}$ & & $\begin{array}{c}-65066.42 \\
71218 \\
0.093\end{array}$ & & $\begin{array}{c}-41809.64 \\
46611 \\
11.8\end{array}$ & \\
\hline
\end{tabular}

Robust standard errors in parentheses. ${ }^{* * *} \mathrm{p}<0.01,{ }^{* *} \mathrm{p}<0.05,{ }^{*} \mathrm{p}<0.1$. The table reports marginal effects for the outcomes "price increase" and "price decrease", respectively, setting all variables at their mean. For binary regressors, the effect is for discrete change from 0 to 1 . I additionally include but don't report firm-specific averages of the individual-specific variables, sectoral dummies as well as Taylor dummies for six and 18 months, respectively. 
Table 5: Ordered Probit Regressions II

\begin{tabular}{|c|c|c|c|c|}
\hline & \multicolumn{2}{|c|}{ (3) } & \multicolumn{2}{|c|}{ (4) } \\
\hline & Increases & Decreases & Increases & Decreases \\
\hline $\begin{array}{l}\text { firm-spec. } \\
\text { inflation }\end{array}$ & $\begin{array}{c}\text { robust } \\
0.018^{* * *} \\
(0.005)\end{array}$ & $\begin{array}{c}\text { robust } \\
-0.014^{* * *} \\
(0.004)\end{array}$ & $\begin{array}{c}\text { robust } \\
0.002 \\
(0.006)\end{array}$ & $\begin{array}{l}\text { robust } \\
-0.002 \\
(0.005)\end{array}$ \\
\hline oil & $\begin{array}{c}0.062^{* * *} \\
(0.013)\end{array}$ & $\begin{array}{c}-0.049 * * * \\
(0.011)\end{array}$ & $\begin{array}{c}0.086^{* * *} \\
(0.014)\end{array}$ & $\begin{array}{c}-0.067^{* * *} \\
(0.011)\end{array}$ \\
\hline exchrate & $\begin{array}{c}0.013 \\
(0.019)\end{array}$ & $\begin{array}{l}-0.010 \\
(0.015)\end{array}$ & $\begin{array}{c}0.054 \\
(0.019)\end{array}$ & $\begin{array}{l}-0.042 \\
(0.015)\end{array}$ \\
\hline EUR & $\begin{array}{c}0.037^{* * *} * \\
(0.010)\end{array}$ & $\begin{array}{c}-0.027^{* * *} \\
(0.006)\end{array}$ & $\begin{array}{c}0.007 \\
(0.010)\end{array}$ & $\begin{array}{l}-0.006 \\
(0.008)\end{array}$ \\
\hline VAT & $\begin{array}{c}0.079^{* * *} \\
(0.007) \\
\end{array}$ & $\begin{array}{c}-0.053^{* * *} \\
(0.004) \\
\end{array}$ & $\begin{array}{c}0.061^{* * *} \\
(0.007)\end{array}$ & $\begin{array}{c}-0.042^{* * *} \\
(0.004) \\
\end{array}$ \\
\hline pr_man & $\begin{array}{c}0.045^{* * *} \\
(0.007)\end{array}$ & $\begin{array}{c}-0.035^{* * *} \\
(0.005)\end{array}$ & $\begin{array}{c}0.007 \\
(0.013)\end{array}$ & $\begin{array}{l}-0.006 \\
(0.010)\end{array}$ \\
\hline pr_ws & $\begin{array}{c}0.328^{* * *} \\
(0.007)\end{array}$ & $\begin{array}{c}-0.258^{* * *} \\
(0.006)\end{array}$ & $\begin{array}{c}0.220^{* * *} \\
(0.011)\end{array}$ & $\begin{array}{c}-0.172^{* * *} \\
(0.009)\end{array}$ \\
\hline pr_ws (11) & & & $\begin{array}{c}0.144^{* * *} \\
(0.012)\end{array}$ & $\begin{array}{c}-0.112^{* * *} \\
(0.009)\end{array}$ \\
\hline pr_ws (12) & & & $\begin{array}{c}-0.029^{* *} \\
(0.012)\end{array}$ & $\begin{array}{c}0.023^{* *} \\
(0.009)\end{array}$ \\
\hline pr_ws (13) & & & $\begin{array}{c}0.007 \\
(0.012)\end{array}$ & $\begin{array}{l}-0.005 \\
(0.009)\end{array}$ \\
\hline pr_ws (14) & & & $\begin{array}{c}-0.037^{* * *} \\
(0.011)\end{array}$ & $\begin{array}{c}0.029^{* * *} * \\
(0.009)\end{array}$ \\
\hline pr_ws (15) & & & $\begin{array}{c}-0.038^{* * *} \\
(0.012)\end{array}$ & $\begin{array}{c}0.030^{* * *} \\
(0.009)\end{array}$ \\
\hline pr_ws (16) & & & $\begin{array}{c}0.057^{* * *} \\
(0.011) \\
\end{array}$ & $\begin{array}{c}-0.044^{* * *} \\
(0.008) \\
\end{array}$ \\
\hline pr_man (11) & & & $\begin{array}{c}0.097 * * * \\
(0.015)\end{array}$ & $\begin{array}{c}-0.075^{* * *} \\
(0.012)\end{array}$ \\
\hline pr_man (12) & & & $\begin{array}{c}-0.030^{* *} \\
(0.015)\end{array}$ & $\begin{array}{c}0.023^{* *} \\
(0.012)\end{array}$ \\
\hline pr_man (13) & & & $\begin{array}{c}-0.107^{* * *} \\
(0.015)\end{array}$ & $\begin{array}{c}0.084^{* * *} \\
(0.012)\end{array}$ \\
\hline pr_man (14) & & & $\begin{array}{c}-0.049 * * * \\
(0.015)\end{array}$ & $\begin{array}{c}0.038^{* * *} \\
(0.012)\end{array}$ \\
\hline pr_man (15) & & & $\begin{array}{c}0.063^{* * *} \\
(0.015)\end{array}$ & $\begin{array}{c}-0.049^{* * *} \\
(0.011)\end{array}$ \\
\hline pr_man (16) & & & $\begin{array}{c}0.095^{* * *} \\
(0.013) \\
\end{array}$ & $\begin{array}{c}-0.074^{* * *} \\
(0.010)\end{array}$ \\
\hline $\begin{array}{l}\text { taylor_j } \\
\text { season }\end{array}$ & $\begin{array}{c}\text { robust } \\
\text { not sign. }\end{array}$ & $\begin{array}{c}\text { robust } \\
\text { not sign. }\end{array}$ & $\begin{array}{c}\text { robust } \\
\text { not sign. }\end{array}$ & $\begin{array}{c}\text { robust } \\
\text { not sign. }\end{array}$ \\
\hline $\begin{array}{l}\text { Log-Lik. } \\
\text { Obs. } \\
\text { Ps.-R2 }\end{array}$ & $\begin{array}{c}-41809.64 \\
46611 \\
0.118\end{array}$ & & $\begin{array}{c}-33535.55 \\
38100 \\
0.114\end{array}$ & \\
\hline
\end{tabular}

Robust standard errors in parentheses. ${ }^{* * *} \mathrm{p}<0.01,{ }^{* *} \mathrm{p}<0.05,{ }^{*} \mathrm{p}<0.1$. The table reports marginal effects for the outcomes "price increase" and "price decrease", respectively, setting all variables at their mean. For binary regressors, the effect is for discrete change from 0 to 1 . I additionally include but don't report firm-specific averages of the individual-specific variables, sectoral dummies, seasonal dummies as well as Taylor dummies for six, 12, 18 and 24 months, respectively. 


\subsection{Goodness of Fit Comparison}

As the last subsections show, state-dependent factors are significant determinants of the probability of observing a price change next to time-dependent elements. For an evaluation of the different price setting theories, however, it is interesting whether a pure "state-dependent" specification is able to outperform an econometric model containing only time-dependent elements. To answer this question, Table 6 reports the percent correctly predicted for different specifications. $^{25}$

Table 6: Percent Correctly Predicted

\begin{tabular}{|l|c|c|c|c|c|}
\hline & "Full Model" (3) & Model (1) & Model (2) & TDP Model & SDP Model \\
\hline PCP overall & $57.24 \%$ & $53.73 \%$ & $56.68 \%$ & $53.02 \%$ & $56.92 \%$ \\
PCP $y_{i t}=1$ & $33.98 \%$ & $27.56 \%$ & $19.55 \%$ & $23.81 \%$ & $34.00 \%$ \\
PCP $y_{i t}=-1$ & $17.43 \%$ & $20.59 \%$ & $14.72 \%$ & $16.26 \%$ & $15.77 \%$ \\
\hline
\end{tabular}

Table 6 shows that the "full model" including all state- and time-dependent variables (see specification (3) in Table 4) predicts the actual outcomes correctly in $57.2 \%$ of the cases. This is clearly superior compared to a model excluding all state-dependent regressors, indicated by "TDP model" in column five of the table (53.0\%). By contrast, a "state-dependent" model ("SDP Model") excluding Taylor as well as seasonal dummies performs much better. In fact, the percent correctly predicted by the SDP model of $56.9 \%$ is quite close to the performance of the full model. This suggests that the addition of time-dependent variables does not improve the model's fit to a large extent. The difference between the full and the TDP model in terms of correctly predicting price increases is even larger (23.8\% versus $34.0 \%)$ indicating that the purely time-dependent specification is especially inappropriate for analyzing the frequency of price increases. Contrarily, in terms of predicting outcome 1, the SDP model does as well as the full model.

A further comparison of the percent correctly predicted of specifications (1) and (2) reveals that an inclusion of the macroeconomic variables as well as the measures of intermediate input prices leads to a clear improvement in performance. Thus, while the firm-specific measures significantly change the repricing probability and improve the model fit, they are not as important for the overall performance of the model as the set of cumulative macro factors as well as the input cost measures. The finding that macroeconomic variables seem to be more important in terms of model fit than the firm-specific measures is not in line with some of the existing studies on price setting using item-level data. These studies generally report a less pronounced role of aggregate

\footnotetext{
${ }^{25}$ In particular, the predicted probabilities are calculated for the three respective outcomes $y_{i t}=1 y_{i t}=-1$ and $y_{i t}=0$, given the explanatory variables. It is assumed that the model predicts $y_{i t}$ to be 1 , for instance, if the predicted probability for outcome $y_{i t}=1$ is highest relative to the probabilities for $y_{i t}=0$ and $y_{i t}=-1$. The percentage of times the predicted $y_{i t}$ is equal to the actual outcome is the overall percent correctly predicted.
} 
measures for pricing. These diverging results might be related to the fact that I analyse pricing decisions at the firm-level, which, to the extent that firms report some sort of average price development for their products, implies a certain level of aggregation. Apparently, at this level of aggregation macroeconomic factors are more relevant compared to price adjustment at the item-level. A detailed analysis of this issue is, however, beyond the scope of this paper.

\subsection{Assessing Sticky Plan Models}

In order to assess the validity of state-dependent sticky plan models relative to their timedependent counterparts, a bivariate ordered probit model has been estimated that accounts for a possible correlation between the timing of actual price changes and the updating of price expectations. Table 7 shows marginal effects of the regressors for five outcome possibilities; $(1,1)$ : price increase and expected price increase, $(1,0)$ : price increase and no change in price expectations, $(-1,0)$ : price decrease and no change in price expectations, $(0,1)$ : no price change and expected price increase, $(0,-1)$ : no price change and expected price decrease. Results from the Wald test performed to test the independence of equations hypothesis $(\rho=0)$ reported at the bottom of the table show that the null hypothesis is strongly rejected indicating that a bivariate specification leads to a more efficient estimation.

First, as far as outcome $(1,0)$ shown in column three of the table is concerned, the main results of the univariate specification given in Table 4 are robust to a bivariate estimation. While the measure of manufacturing price changes as well as the dummy Taylor 12 are now insignificant, the remaining state-dependent variables are still significant and show the expected signs. Similarly, results for price decreases are robust, as is shown in column four of Table 7. The first column of the table reports marginal effects for outcome $(1,1)$ indicating a simultaneous increase in the realized price and in price expectations. Overall, the results are very similar as compared to those obtained from the univariate specification for price realizations. Most of the firm-specific variables are significant and show the expected signs. Moreover, increases in the rate of sectoral inflation and the Euro/USD exchange rate significantly affect the probability of observing both a price increase and an expected price increase by $1 \%$ and $2.7 \%$, respectively. The measure of an oil price change is insignificant. Importantly, however, the measures of intermediate input costs as well as the institutional dummies are highly significant and have relatively large marginal effects. Columns five and six of Table 7 show the results for the outcomes "no price change" and "expected price increase" as well as "no price change" and "expected price decrease". The results indicate that overall the determinants of price updating are very similar to those of the actual setting of prices. In particular, deteriorations in the state of business, the expected business development as well as decreases in the number of orders significantly decrease (increase) the probability of observing an expected price increase (decrease). Increases in the business volume and in orders lead to a higher (lower) likelihood of a positive (negative) change in price expectations. Moreover, while the introduction of the Euro does not seem to play a role for the 
updating of prices, changes in the VAT rate as well as intermediate input prices are significant and have relatively large effects. Effects of the cumulative macroeconomic variables, however, differ somewhat to those for outcomes $(1,0)$ and $(-1,0)$. While the sectoral rate of inflation is not significantly related to the timing of price updating, cumulative changes in the exchange rate are significant and have the expected sign. Surprisingly, an increase in the cumulative rate of change in the price of oil leads to a lower probability of observing an increase in expected price changes. Arguably, however, it is not clear whether an increase in the price of oil is related to a negative supply or a positive demand shock. In the case of an adverse supply shock, expected negative effects on economic activity could offset upward pressures on expected future prices via a reduced world demand thereby leading to the observed negative (positive) effects on the probability of observing an increase (decrease) in price expectations.

Overall, the main conclusion resulting from the bivariate specification is that the underlying determinants of price updating are very similar to those of the price setting process. ${ }^{26}$ In particular, next to time-dependent variables, most of the factors characterizing the state of the firm as well as the state of the economy are highly significant and show the expected signs. Thus, while these findings are in line with, for instance, the sticky plan model of Burstein (2006) assuming a state-dependent process of price updating, time-dependent sticky information models are not supported by the results.

\subsection{Robustness Checks}

In order to check for robustness of the results, several variations of specification (3) for price realizations are estimated. The corresponding results are shown in Table B9 in Appendix B. First, I include a measure of cumulative changes in the aggregate rate of CPI inflation instead of the respective sectoral rates; the main results are robust to this variation. Moreover, results are robust to the exclusion of the firm-specific means of the individual-specific variables. To account for possible endogeneity of the firm-specific variables, in an alternative specification these measures enter in first lags. The coefficients of these variables are still highly significant suggesting that endogeneity problems associated with these variables are unlikely. Finally, the main results are still valid if the macroeconomic variables enter as month-on-month changes. A further robustness check concerns the variables measuring the macroeconomic situation of the firms. Arguably, the variables that I include in the benchmark specification only represent a certain selection of relevant factors and may not cover the entire economic environment facing the firms. To account for this I additionally estimate a modification of specification (2) where I include time-specific effects instead of the cumulative macroeconomic variables. Thus, dummies for every month are included in the estimation in order to account for all relevant macroeconomic

\footnotetext{
${ }^{26}$ The main results are qualitatively very similar in a univariate regression with the probability of observing a change in price expectations as dependent variable. Regression results are available from the author upon request.
} 
and institutional factors in a given month. Estimation results are given in Table B10 in Appendix B. It can be seen that all other variables are robust to including time-specific effects. Moreover, as in the benchmark estimation adding the variables reflecting the macro environment improves the model fit pointing to the importance of the overall economic environment for the price adjustment decision. Results of the Wald test reported in Table B10 indicate that the time dummies are jointly significant at the $1 \%$ level. Furthermore, most of the time effects are individually significant.

Furthermore, to control for possible asymmetries between the data generating process of price increases and decreases, respectively, specification (3) is estimated using separate logit specifications for outcomes $y_{i t}=1$ and $y_{i t}=-1$. Results are reported in columns two and three of Table B11 in Appendix B. It can be seen that results are largely in line with those based on the ordered probit estimation suggesting that using a symmetric specification is a valid approach. The only exceptions are the rate of inflation, the Euro dummy as well as the oil price. While changes in the rate of inflation are important for the probability of a price increase, the variable is insignificant for price decreases. This result is plausible in an environment of positive inflation. Similarly, the introduction of the Euro as well as some of the seasonal dummies are important only for price increases.

Finally, to check for robustness of the results under a different estimation strategy, specification (3) is additionally estimated using a linear regression model. In contrast to the "pooled" ordered probit model, this method allows for an easy implementation of individual-specific effects that capture unobserved heterogeneity. While the more structural nonlinear index models like ordered probit lead to more efficient estimators if the distributional assumptions are correct, estimators obtained by using the linear model are always consistent. Columns four and five of Table B11 reports the coefficients from the linear regression both with and without fixed effects. Qualitatively, the main results are unaffected by using a different estimation method. Moreover, the marginal effects calculated for the ordered probit coefficients show a similar order of magnitude as the coefficients from the linear model further reinforcing the validity of the key conclusions stated above. Finally, a linear specification allows me to easily apply an instrumental variables estimation. Column six of table B11 reports the results of a two stage least square instrumental variables estimation with the dummies indicating changes in the business volume, expected orders and the expected business development assumed to be endogenous. As instruments I consider first lags of the endogenous regressors. ${ }^{27}$ The results show that with the exception of increases in the business volume, all firm-specific variables are robust to estimating an IV specification.

\footnotetext{
${ }^{27}$ Results of the first stage regression indicate that these measures are significant and represent strong instruments. Results are available upon request.
} 
Table 7: Price Realizations and Expectations - Bivariate Ordered Probit Regression

\begin{tabular}{|c|c|c|c|c|c|}
\hline & $(1,1)$ & $(1,0)$ & $(-1,0)$ & $(0,1)$ & $(0,-1)$ \\
\hline statebus $^{-}$ & $\begin{array}{c}-0.026^{* * *} \\
(0.002)\end{array}$ & $\begin{array}{c}-0.006^{* * *} \\
(0.002)\end{array}$ & $\begin{array}{c}0.014^{* * *} \\
(0.002)\end{array}$ & $\begin{array}{c}-0.021^{* * *} \\
(0.003)\end{array}$ & $\begin{array}{c}0.013^{* * *} \\
(0.002)\end{array}$ \\
\hline busvol $^{-}$ & $\begin{array}{c}0.007^{* * *} \\
(0.002)\end{array}$ & $\begin{array}{c}-0.007^{* * *} \\
(0.002)\end{array}$ & $\begin{array}{c}0.002 \\
(0.002)\end{array}$ & $\begin{array}{c}0.018^{* * *} \\
(0.003)\end{array}$ & $\begin{array}{c}-0.009^{* * *} \\
(0.001)\end{array}$ \\
\hline orders $^{-}$ & $\begin{array}{c}-0.028^{* * *} \\
(0.003)\end{array}$ & $\begin{array}{c}-0.005^{* *} \\
(0.002)\end{array}$ & $\begin{array}{c}0.014^{* * *} \\
(0.002)\end{array}$ & $\begin{array}{c}-0.026^{* * *} \\
(0.003)\end{array}$ & $\begin{array}{c}0.016^{* * *} \\
(0.002)\end{array}$ \\
\hline busdev $^{-}$ & $\begin{array}{c}-0.029^{* * *} \\
(0.003)\end{array}$ & $\begin{array}{c}-0.007 * * * \\
(0.002)\end{array}$ & $\begin{array}{c}0.016^{* * *} \\
(0.002)\end{array}$ & $\begin{array}{c}-0.025^{* * *} \\
(0.003)\end{array}$ & $\begin{array}{c}0.016^{* * *} \\
(0.002)\end{array}$ \\
\hline statebus $^{+}$ & $\begin{array}{c}0.003 \\
(0.003)\end{array}$ & $\begin{array}{c}0.008^{* *} \\
(0.004)\end{array}$ & $\begin{array}{c}-0.006^{* *} \\
(0.003)\end{array}$ & $\begin{array}{c}-0.006 \\
(0.004)\end{array}$ & $\begin{array}{c}0.003 \\
(0.002)\end{array}$ \\
\hline busvol $^{+}$ & $\begin{array}{c}0.029 * * * \\
(0.003)\end{array}$ & $\begin{array}{c}0.011^{* * *} \\
(0.002)\end{array}$ & $\begin{array}{c}-0.017^{* * *} \\
(0.002)\end{array}$ & $\begin{array}{c}0.016^{* * *} \\
(0.003)\end{array}$ & $\begin{array}{c}-0.011^{* * *} \\
(0.002)\end{array}$ \\
\hline orders $^{+}$ & $\begin{array}{c}-0.011^{* * *} \\
(0.004)\end{array}$ & $\begin{array}{c}-0.018^{* * *} \\
(0.004)\end{array}$ & $\begin{array}{c}0.017^{* * *} \\
(0.004)\end{array}$ & $\begin{array}{c}0.013^{* *} \\
(0.006)\end{array}$ & $\begin{array}{c}-0.005^{*} \\
(0.003)\end{array}$ \\
\hline busdev $^{+}$ & $\begin{array}{c}-0.024^{* * *} \\
(0.003)\end{array}$ & $\begin{array}{c}-0.013^{* * *} \\
(0.003)\end{array}$ & $\begin{array}{c}0.018^{* * *} \\
(0.003) \\
\end{array}$ & $\begin{array}{c}-0.012^{* * *} \\
(0.004) \\
\end{array}$ & $\begin{array}{c}0.009^{* * *} \\
(0.003)\end{array}$ \\
\hline inflation & $\begin{array}{c}0.010^{* * * *} \\
(0.003)\end{array}$ & $\begin{array}{c}0.007^{* * *} \\
(0.002)\end{array}$ & $\begin{array}{c}-0.009 * * * \\
(0.002)\end{array}$ & $\begin{array}{c}0.002 \\
(0.003)\end{array}$ & $\begin{array}{l}-0.002 \\
(0.002)\end{array}$ \\
\hline oil & $\begin{array}{c}0.004 \\
(0.008)\end{array}$ & $\begin{array}{c}0.048^{* * *} \\
(0.007)\end{array}$ & $\begin{array}{c}-0.032^{* * *} \\
(0.007)\end{array}$ & $\begin{array}{c}-0.059^{* * *} \\
(0.010)\end{array}$ & $\begin{array}{c}0.028^{* * *} \\
(0.005)\end{array}$ \\
\hline exchrate & $\begin{array}{c}0.027^{* *} \\
(0.011)\end{array}$ & $\begin{array}{l}-0.010 \\
(0.010)\end{array}$ & $\begin{array}{c}-0.004 \\
(0.009)\end{array}$ & $\begin{array}{c}0.043^{* * *} \\
(0.013)\end{array}$ & $\begin{array}{c}-0.024^{* * *} \\
(0.007)\end{array}$ \\
\hline EUR & $\begin{array}{c}0.019^{* * *} \\
(0.006)\end{array}$ & $\begin{array}{c}0.016^{* * *} \\
(0.005)\end{array}$ & $\begin{array}{c}-0.016^{* * *} \\
(0.004)\end{array}$ & $\begin{array}{l}-0.001 \\
(0.006)\end{array}$ & $\begin{array}{c}-0.002 \\
(0.003)\end{array}$ \\
\hline VAT & $\begin{array}{c}0.063^{* * *} \\
(0.004)\end{array}$ & $\begin{array}{c}0.017^{* * *} \\
(0.003)\end{array}$ & $\begin{array}{c}-0.032^{* * *} \\
(0.002)\end{array}$ & $\begin{array}{c}0.034^{* * *} \\
(0.004)\end{array}$ & $\begin{array}{c}-0.022^{* * * *} \\
(0.002)\end{array}$ \\
\hline pr_ws & $\begin{array}{c}0.189^{* * *} \\
(0.004)\end{array}$ & $\begin{array}{c}0.130^{* * *} \\
(0.004)\end{array}$ & $\begin{array}{c}-0.154^{* * *} \\
(0.004)\end{array}$ & $\begin{array}{c}0.041^{* * *} \\
(0.005)\end{array}$ & $\begin{array}{c}-0.041^{* * *} \\
(0.003)\end{array}$ \\
\hline pr_man & $\begin{array}{c}0.045^{* * *} \\
(0.004) \\
\end{array}$ & $\begin{array}{c}0.004 \\
(0.003) \\
\end{array}$ & $\begin{array}{c}-0.020^{* * *} \\
(0.003) \\
\end{array}$ & $\begin{array}{c}0.045^{* * *} \\
(0.004) \\
\end{array}$ & $\begin{array}{c}-0.027^{* * *} * \\
(0.002)\end{array}$ \\
\hline Taylor12 & $\begin{array}{c}0.022^{* * *} \\
(0.002)\end{array}$ & $\begin{array}{c}0.000 \\
(0.002)\end{array}$ & $\begin{array}{c}-0.009 * * * \\
(0.002)\end{array}$ & $\begin{array}{c}0.023^{* * *} \\
(0.003)\end{array}$ & $\begin{array}{c}-0.014^{* * *} \\
(0.001)\end{array}$ \\
\hline Taylor24 & $\begin{array}{l}-0.003 \\
(0.002)\end{array}$ & $\begin{array}{c}-0.013^{* * *} \\
(0.002)\end{array}$ & $\begin{array}{c}0.009 * * * \\
(0.002)\end{array}$ & $\begin{array}{c}0.014^{* * *} \\
(0.003)\end{array}$ & $\begin{array}{c}-0.006^{* * *} \\
(0.001)\end{array}$ \\
\hline winter & $\begin{array}{c}0.022^{* * *} \\
(0.003)\end{array}$ & $\begin{array}{c}-0.013^{* * *} \\
(0.002)\end{array}$ & $\begin{array}{l}-0.001 \\
(0.002)\end{array}$ & $\begin{array}{c}0.043^{* * *} \\
(0.003)\end{array}$ & $\begin{array}{c}-0.021^{* * *} \\
(0.002)\end{array}$ \\
\hline summer & $\begin{array}{c}0.033^{* * *} \\
(0.003)\end{array}$ & $\begin{array}{c}-0.026^{* * *} \\
(0.002)\end{array}$ & $\begin{array}{c}0.001 \\
(0.002)\end{array}$ & $\begin{array}{c}0.073^{* * *} \\
(0.003)\end{array}$ & $\begin{array}{c}-0.034^{* * *} \\
(0.001)\end{array}$ \\
\hline fall & $\begin{array}{c}0.017^{* * *} \\
(0.003)\end{array}$ & $\begin{array}{c}-0.018^{* * *} \\
(0.002)\end{array}$ & $\begin{array}{l}0.004^{*} \\
(0.002)\end{array}$ & $\begin{array}{c}0.043^{* * *} \\
(0.003)\end{array}$ & $\begin{array}{c}-0.021^{* * *} \\
(0.002)\end{array}$ \\
\hline $\begin{array}{l}\text { Log-Lik. } \\
\text { Obs. } \\
\text { Wald Test of } \\
\text { Independence }\end{array}$ & \multicolumn{5}{|c|}{$\begin{array}{l}-81859.046 \\
46611 \\
\text { Prob }>\text { chi2 }=0.0000\end{array}$} \\
\hline
\end{tabular}

Robust standard errors in parentheses. ${ }^{* * *} \mathrm{p}<0.01,{ }^{* *} \mathrm{p}<0.05,{ }^{*} \mathrm{p}<0.1$. The table reports marginal effects for the following outcomes: $(1,1)$ - "price increase" and "increase in expectation", $(1,0)$ - "price increase" and "no change in expectation", (-1,0) - "price decrease" and "no change in expectation", $(0,1)$ - " no price change" and "increase in expectation", (0,-1) - " no price change" and "decrease in expectation", respectively. All variables are set at their mean. For binary regressors, the effect is for discrete change from 0 to 1 . I additionally include but don't report firm-specific averages of the individual-specific variables, sectoral dummies as well as Taylor dummies for six and 18 months, respectively. 


\section{Conclusion}

This paper contributes to the empirical literature on price setting by analyzing three main questions concerning the price setting and updating behaviour of German retail firms using a new firm-level dataset over the period 1991-2006. The first main issue addressed is whether the price adjustment decision by firms is driven by time- or state-dependence. Regressing the price adjustment probability not only on time-dependent and macroeconomic variables but also on factors characterizing the individual-specific condition of firms, I find that next to timedependent variables such as Taylor dummies most state-dependent factors significantly change the repricing probability. Cumulative changes in the sectoral rate of inflation and the oil price as well as the introduction of the Euro or changes in the VAT rate significantly affect the timing of price adjustment. Moreover, most of the variables describing the specific state of the firm turn out to be highly significant. For instance, deteriorations in the state of business or the expected business development as well as decreases in orders significantly decrease the probability to observe a price increase and, vice versa, raise the chance of a price decrease. This confirms the important role of state-dependence for price adjustment. Moreover, simple goodness of fit measures of different model specifications show that a purely time-dependent specification performs poorly relative to a model including state-dependent measures. This is not in line with standard time-dependent theories à la Calvo (1983) or Taylor (1980). Instead, the results suggest that price setting models should endogenize the timing of price adjustment to realistically predict the effects of monetary policy as is done by, for instance, Dotsey et al. (1999) or Golosov and Lucas (2007).

With respect to the importance of intermediate variables, regression results show first, that input price variability is indeed a relevant determinant for price adjustment in retail. Explicitly modeling the transmission of price shocks through the chain of production is thus a valid approach. However, regression results show that it takes time for retail prices to adjust to input cost changes suggesting that there is "additional rigidity" at the retail level. This is not accounted for in pricing models with an explicit production structure such as Basu (1995) or Huang and Liu (2001).

Finally, using a bivariate specification that accounts for the correlation between the setting of actual prices and price plans, I find that changes in price expectations are driven by similar factors as changes in actual prices. Most of the firm-specific variables, macroeconomic measures as well as institutional dummies are highly significant and economically important. This implies that sticky information models by, for instance, Caballero (1989) and Mankiw and Reis (2002, 2006) assuming time-dependent updating of future prices are not supported by the results. By contrast, the results are in line with the model by Burstein (2006) and Alvarez et al. (2010) that assume a menu cost of changing plans of future prices. 


\section{Appendix A. Data}

\section{Appendix A.1. Business Survey Data}

Since 1949 the Ifo Institute for Economic Research has been analyzed economic developments in Germany using monthly business surveys (see Becker and Wohlrabe (2008) for more details on the variables contained in the survey). In the questionnaires firms are asked about the development of certain key measures such as the number of orders and business volume, the perceived state of business as well as the development of prices. A distinct feature of the survey data is that it contains firm-specific information on expectations concerning the future business development as well as future prices. While the data is mainly used for the construction and analysis of business tendency indicators, the fact that the survey contains economic measures characterizing the specific state of the individual firms allows to analyze a variety of other issues at well. As has been emphasized in the main text, in this paper I only analyze data concerning the retail sector. In 2003, the average number of retail firms surveyed each month was 900, while the average response rate was about $70 \%$. The participating firms' share of total revenues generated in the retail sector was about $10 \%$. The following list gives an overview of the precise wording of the questions asked for the variables used in this paper.

Development in reporting month:

- Relative to the previous month, our sales prices were (1) increased, (2) not changed, (3) decreased

- We currently assess our state of business as (1) good, (2) satisfactory, (3) bad

- Relative to the previous month, our business volume was (1) increased, (2) not changed, (3) decreased

Plans and Expectations:

- In the next three months we expect our sales prices to (1) increase, (2) not change, (3) decrease

- In the next three months we expect the number of orders to (1) increase, (2) not change, (3) decrease

- In the next six months we expect our business development to be (1) more favourable, (2) not changed, (3) less favourable 
In order to judge to what extent the business surveys capture the price developments actually realized by the firms, it is important to know who actually answers the questionnaires. According to Abberger et al. (2009), for small and medium-sized firms, in almost $90 \%$ of the cases the surveys are answered by the firm owner, the CEO or another member of the company's board. In the case of large firms, almost $70 \%$ of the survey are answered by the latter group while in about $20 \%$ of the cases the questions are answered by department managers (see Figure A.14). Moreover, as can be seen in the figure, if firms are asked in which department of the company the questionnaires are filled out, about $90 \%$ of small and medium-sized firms report "management". For large firms, the questionnaires are answered within the management department in almost $80 \%$ of the cases. Thus, overall, the questionnaires are answered at a very high level of expertise suggesting that they reliably reflect actual price developments.

A final issue concerns the price development reported by multi-product firms. Arguably, the inclusion of multi-product firms in the survey may lead to an upward bias of the frequency of price changes. For instance, in an extreme case a firm may report a price change even though only the price of one major product has been adjusted. In the survey, this problem is mitigated because multi-product firms are asked to fill out several questionnaires for different product groups. To the extent that firms still have to cluster several sub-products within the same reporting category, about half of the respondents report the average price development of all their products $(43.3 \%)$ or give information on prices of their most important products in terms of business volume $(44.6 \%)$. Only $10 \%$ report the price devlopment of their main product, while $3.7 \%$ use other practices in reporting their price development (Abberger et al., 2009).

Figure A.2: Position of the person and department in charge of answering the questionnaires
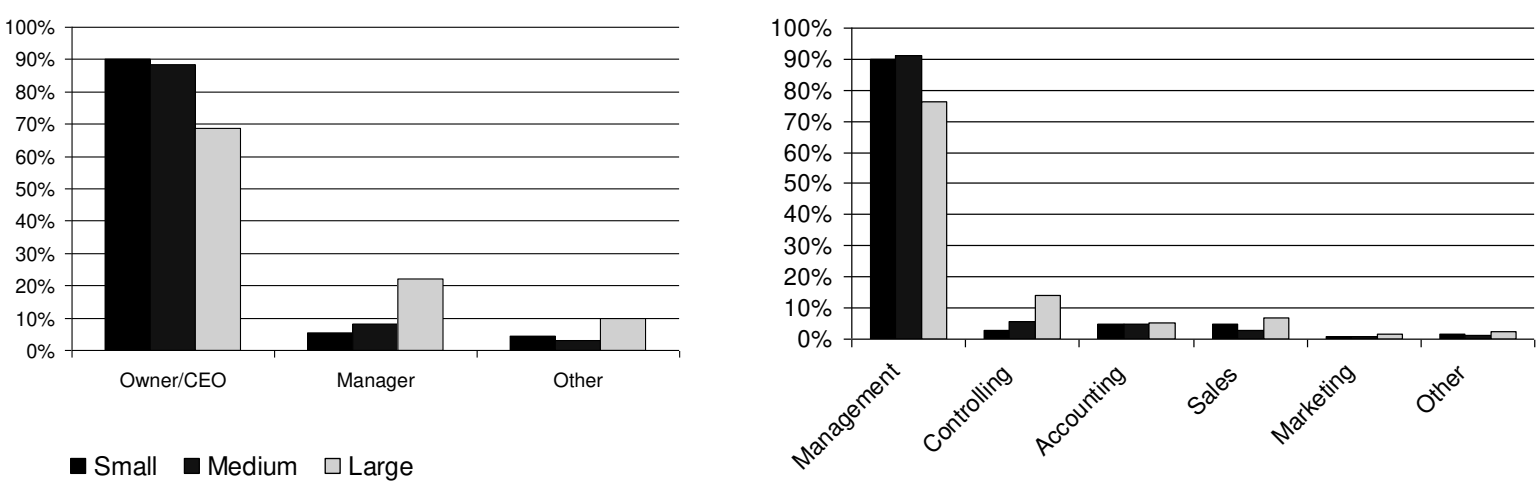

Left panel, question asked: Which position does the person in charge of answering the questionnaire have in your company? Right panel, question asked: In which department of your company is the survey usually answered? Since firms may report several departements, percentages don't always add up to 100. 


\section{Appendix A.2. Accounting for Sales}

The survey dataset does not contain information on whether a price change is related to temporary sales. I account for the existence of temporary sales in the data by using a "sales filter" proposed in the literature. In particular, I identify these price changes by looking for "V-shaped" patterns in the data using a "sale filter" similar to the one proposed by Nakamura and Steinsson (2008a). A price change is labeled "sale" if there is a one-time price decrease that is followed by a price increase. I define different windows for the time it takes for a decrease to be followed by an increase; I consider one to three months, labeled as window 1, 2 and 3, respectively. Once price changes related to sales are identified by the filter, they are removed by assigning these observations to the group of "no changes". Observations indicating a price decrease $(-1)$ due to a sale are thus replaced by (0). For a detailed discussion of this approach, see Nakamura and Steinsson (2008a).

Table A.8 displays the mean frequencies, standard deviations as well as the correlation with the overall rate of retail price inflation of price changes for the original data as well as for the filtered data using the sales filter with different window sizes. As can be seen in the table, removing sales from the data does not cause changes in the statistics related to the extensive margin. The mean frequency of price changes only decreases slightly from $27.32 \%$ for the original data to $26.7 \%, 26.2 \%$ and $25.86 \%$ for the filtered data using window 1, 2 and 3, respectively. Similarly, the standard deviations for the different series are almost the same decreasing only slightly for the filtered data. Thus, the occurrence of sales as identified by the procedure described above is not a frequent phenomenon in our data as compared to U.S. data reported in, for instance, Nakamura and Steinsson (2008a). Moreover, using the filter does not influence the correlation with the rate of inflation indicating that the exclusion of sales does not alter the macroeconomic interpretation of the results. Furthermore, regression results are robust to excluding price decreases due to sales. ${ }^{28}$

Table A.8: Summary Statistics for the Extensive Margin- Excluding Sales

\begin{tabular}{l|rrr}
\hline \hline & Mean & Std. dev. & Corr. with \\
Variable & $(\%)$ & $(\%)$ & $\pi_{t}$ \\
\hline Original data & 27.32 & 7.26 & 0.18 \\
Sale filter, window 1 & 26.70 & 7.09 & 0.17 \\
Sale filter, window 2 & 26.20 & 7.02 & 0.18 \\
Sale filter, window 3 & 25.86 & 7.08 & 0.19 \\
\hline \hline
\end{tabular}

Notes: Sample runs from 1990:01 to 2006:01 with monthly frequency. The retail price index is obtained from the Federal Bureau of Statistics. Lines 2-4 show results from filtered data.

\footnotetext{
${ }^{28}$ Results are available upon request.
} 


\section{Appendix B. Tables and Figures}

Figure B.3: Aggregated Micro Retail Price Data and Retail Price Index

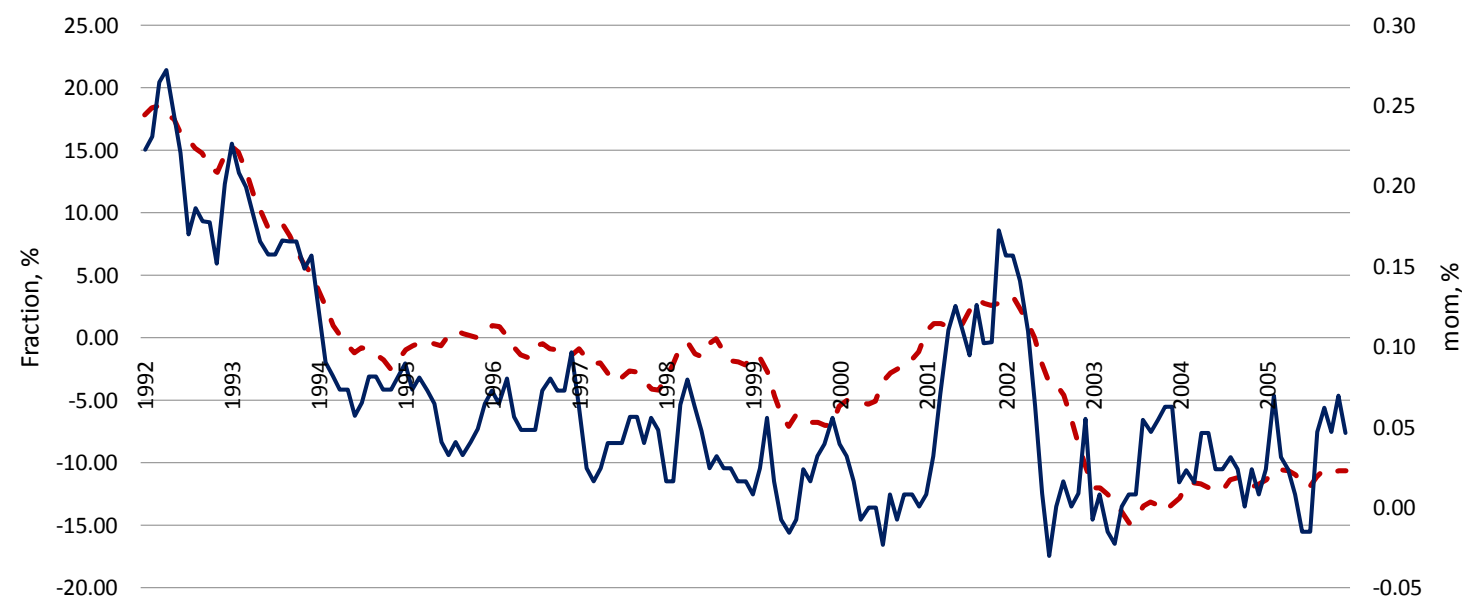

- Microdata - Net Price Increases (left scale) - Official Retail Price Index (right scale) 
Figure B.4: Aggregated Micro Retail Price Data and Retail Price Index - Sectors
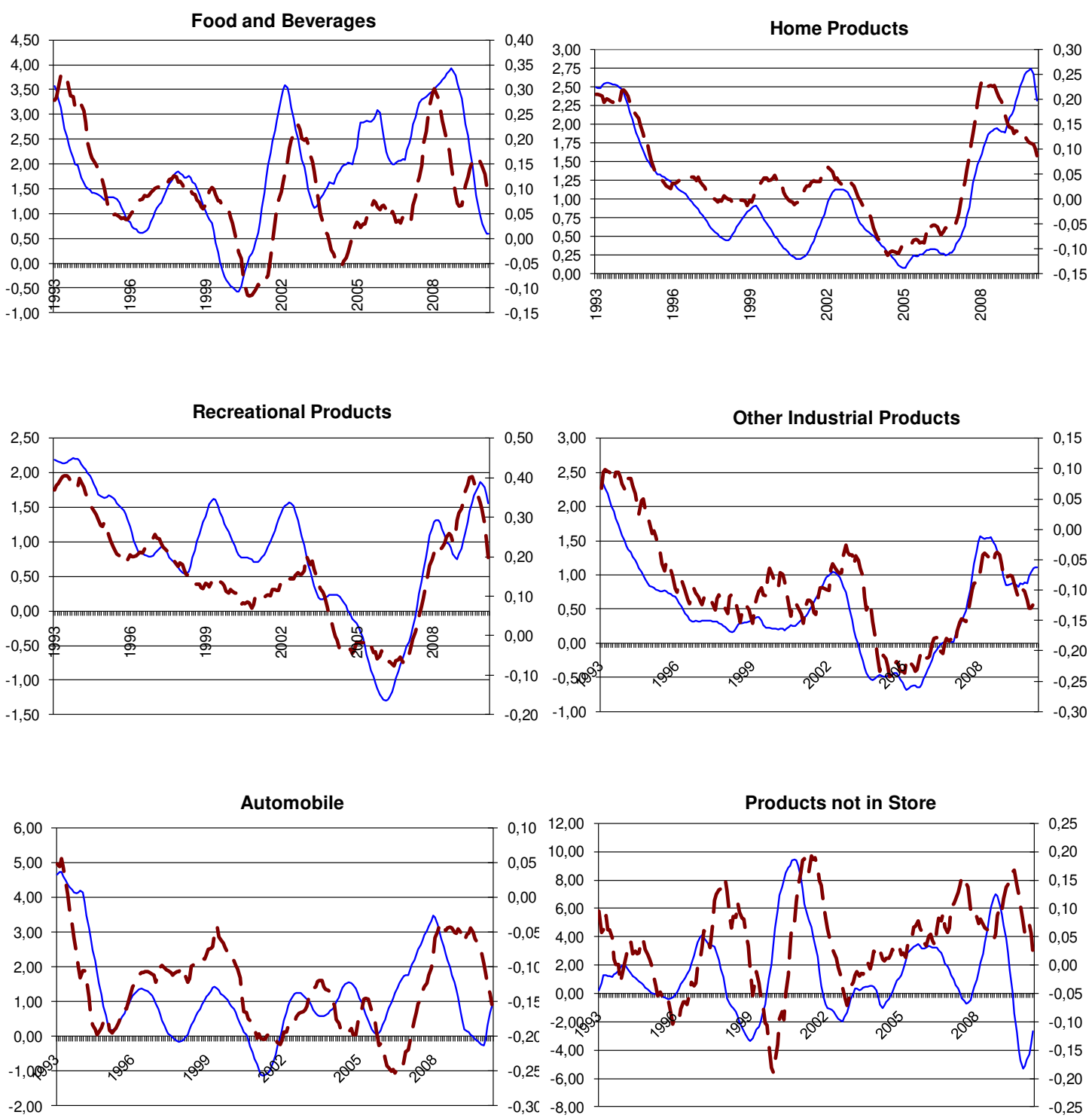
Table B.9: Robustness Checks - Ordered Probit Regressions, Price Realizations

\begin{tabular}{|c|c|c|c|c|c|c|c|c|}
\hline & \multicolumn{2}{|c|}{ (3a) } & \multicolumn{2}{|c|}{$(3 b)$} & \multicolumn{2}{|c|}{$(3 \mathrm{c})$} & \multicolumn{2}{|c|}{$(3 \mathrm{~d})$} \\
\hline & Incr & Decr & Incr & Decr & Incr & Decr & Incr & Decr \\
\hline statebus $^{-}$ & $\begin{array}{c}-0.031^{* * *} \\
(0.004)\end{array}$ & $\begin{array}{c}0.025^{* * *} \\
(0.003)\end{array}$ & $\begin{array}{c}-0.036^{* * *} \\
(0.004)\end{array}$ & $\begin{array}{c}0.029 * * * \\
(0.003)\end{array}$ & $\begin{array}{c}-0.030^{* * *} \\
(0.004)\end{array}$ & $\begin{array}{c}0.025^{* * *} \\
(0.003)\end{array}$ & $\begin{array}{c}-0.014^{* * *} \\
(0.004)\end{array}$ & $\begin{array}{c}0.012^{* * *} \\
(0.003)\end{array}$ \\
\hline busvol $^{-}$ & $\begin{array}{l}-0.003 \\
(0.004)\end{array}$ & $\begin{array}{c}0.002 \\
(0.003)\end{array}$ & $\begin{array}{c}-0.001 \\
(0.004)\end{array}$ & $\begin{array}{c}0.001 \\
(0.003)\end{array}$ & $\begin{array}{l}-0.005 \\
(0.004)\end{array}$ & $\begin{array}{c}0.004 \\
(0.003)\end{array}$ & $\begin{array}{c}0.027^{* * *} * \\
(0.004)\end{array}$ & $\begin{array}{c}-0.021^{* * *} \\
(0.003)\end{array}$ \\
\hline orders $^{-}$ & $\begin{array}{c}-0.032^{* * *} \\
(0.004)\end{array}$ & $\begin{array}{c}0.025^{* * *} \\
(0.004)\end{array}$ & $\begin{array}{c}-0.040^{* * *} \\
(0.004)\end{array}$ & $\begin{array}{c}0.033^{* * *} \\
(0.003)\end{array}$ & $\begin{array}{c}-0.030^{* * *} \\
(0.004)\end{array}$ & $\begin{array}{c}0.024^{* * *} \\
(0.004)\end{array}$ & $\begin{array}{c}-0.037^{* * *} \\
(0.004)\end{array}$ & $\begin{array}{c}0.030^{* * *} \\
(0.004)\end{array}$ \\
\hline busdev $^{-}$ & $\begin{array}{c}-0.035^{* * *} \\
(0.005)\end{array}$ & $\begin{array}{c}0.029^{* * *} \\
(0.004)\end{array}$ & $\begin{array}{c}-0.040^{* * *} \\
(0.004)\end{array}$ & $\begin{array}{c}0.033^{* * *} \\
(0.004)\end{array}$ & $\begin{array}{c}-0.033^{* * *} \\
(0.005)\end{array}$ & $\begin{array}{c}0.028^{* * *} \\
(0.004)\end{array}$ & $\begin{array}{c}-0.033^{* * *} \\
(0.005)\end{array}$ & $\begin{array}{c}0.027^{* * *} \\
(0.004)\end{array}$ \\
\hline statebus $^{+}$ & $\begin{array}{c}0.015^{* *} \\
(0.006)\end{array}$ & $\begin{array}{c}-0.011^{* *} \\
(0.005)\end{array}$ & $\begin{array}{c}0.021^{* * *} \\
(0.006)\end{array}$ & $\begin{array}{c}-0.016^{* * *} \\
(0.005)\end{array}$ & $\begin{array}{l}0.012^{*} \\
(0.006)\end{array}$ & $\begin{array}{c}-0.010^{*} \\
(0.005)\end{array}$ & $\begin{array}{c}0.008 \\
(0.006)\end{array}$ & $\begin{array}{l}-0.006 \\
(0.005)\end{array}$ \\
\hline busvol $^{+}$ & $\begin{array}{c}0.038^{* * *} \\
(0.005)\end{array}$ & $\begin{array}{c}-0.029 * * * \\
(0.003)\end{array}$ & $\begin{array}{c}0.042^{* * *} \\
(0.005)\end{array}$ & $\begin{array}{c}-0.032^{* * *} \\
(0.003)\end{array}$ & $\begin{array}{c}0.035^{* * *} \\
(0.005)\end{array}$ & $\begin{array}{c}-0.027^{* * *} \\
(0.003)\end{array}$ & $\begin{array}{c}0.027^{* * *} * \\
(0.005)\end{array}$ & $\begin{array}{c}-0.021^{* * *} \\
(0.003)\end{array}$ \\
\hline orders $^{+}$ & $\begin{array}{c}-0.031^{* * *} \\
(0.007)\end{array}$ & $\begin{array}{c}0.026^{* * *} \\
(0.007)\end{array}$ & $\begin{array}{c}-0.019 * * * \\
(0.007)\end{array}$ & $\begin{array}{c}0.015^{* * *} \\
(0.006)\end{array}$ & $\begin{array}{c}-0.029 * * * \\
(0.007)\end{array}$ & $\begin{array}{c}0.025^{* * *} \\
(0.007)\end{array}$ & $\begin{array}{c}-0.016^{* *} \\
(0.008)\end{array}$ & $\begin{array}{c}0.013^{* *} \\
(0.007)\end{array}$ \\
\hline busdev $^{+}$ & $\begin{array}{c}-0.038^{* * *} \\
(0.006)\end{array}$ & $\begin{array}{c}0.032^{* * *} \\
(0.006)\end{array}$ & $\begin{array}{c}-0.030 * * * \\
(0.006)\end{array}$ & $\begin{array}{c}0.025^{* * *} \\
(0.005)\end{array}$ & $\begin{array}{c}-0.040^{* * *} \\
(0.006)\end{array}$ & $\begin{array}{c}0.035^{* * *} \\
(0.006)\end{array}$ & $\begin{array}{c}-0.036^{* * *} \\
(0.006)\end{array}$ & $\begin{array}{c}0.031^{* * *} \\
(0.006)\end{array}$ \\
\hline inflation & $\begin{array}{c}0.018^{* * *} \\
(0.005)\end{array}$ & $\begin{array}{c}-0.014 * * * \\
(0.004)\end{array}$ & $\begin{array}{c}0.017^{* * *} \\
(0.005)\end{array}$ & $\begin{array}{c}-0.013^{* * *} \\
(0.004)\end{array}$ & $\begin{array}{c}0.044^{* * *} \\
(0.006)\end{array}$ & $\begin{array}{c}-0.035^{* * *} \\
(0.005)\end{array}$ & $\begin{array}{c}0.292^{* * *} \\
(0.041)\end{array}$ & $\begin{array}{c}-0.233^{* * *} \\
(0.033)\end{array}$ \\
\hline oil & $\begin{array}{c}0.062^{* * *} \\
(0.013)\end{array}$ & $\begin{array}{c}-0.049^{* * *} \\
(0.011)\end{array}$ & $\begin{array}{c}0.052^{* * *} \\
(0.013)\end{array}$ & $\begin{array}{c}-0.041^{* * *} \\
(0.011)\end{array}$ & $\begin{array}{c}0.004^{* *} \\
(0.002)\end{array}$ & $\begin{array}{c}-0.003^{* *} \\
(0.002)\end{array}$ & $\begin{array}{c}0.046^{* * *} \\
(0.015)\end{array}$ & $\begin{array}{c}-0.037^{* * *} * \\
(0.012)\end{array}$ \\
\hline exchrate & $\begin{array}{c}0.019 \\
(0.019)\end{array}$ & $\begin{array}{l}-0.015 \\
(0.015)\end{array}$ & $\begin{array}{c}0.022 \\
(0.019)\end{array}$ & $\begin{array}{l}-0.017 \\
(0.015)\end{array}$ & $\begin{array}{l}-0.001 \\
(0.001)\end{array}$ & $\begin{array}{c}0.001^{*} \\
(0.001)\end{array}$ & $\begin{array}{l}0.030^{*} \\
(0.019)\end{array}$ & $\begin{array}{l}-0.024 \\
(0.015)\end{array}$ \\
\hline EUR & $\begin{array}{c}0.037^{* * *} \\
(0.010)\end{array}$ & $\begin{array}{c}-0.027^{* * *} \\
(0.006)\end{array}$ & $\begin{array}{c}0.037^{* * * *} \\
(0.009)\end{array}$ & $\begin{array}{c}-0.027^{* * *} \\
(0.006)\end{array}$ & $\begin{array}{c}0.037^{* * *} \\
(0.009)\end{array}$ & $\begin{array}{c}-0.027^{* * *} \\
(0.006)\end{array}$ & $\begin{array}{c}0.035^{* * * *} \\
(0.009)\end{array}$ & $\begin{array}{c}-0.026^{* * *} \\
(0.006)\end{array}$ \\
\hline VAT & $\begin{array}{c}0.079^{* * *} \\
(0.007) \\
\end{array}$ & $\begin{array}{c}-0.053^{* * *} \\
(0.004) \\
\end{array}$ & $\begin{array}{c}0.078^{* * *} \\
(0.007) \\
\end{array}$ & $\begin{array}{c}-0.053^{* * *} \\
(0.004) \\
\end{array}$ & $\begin{array}{c}0.074^{* * *} \\
(0.007) \\
\end{array}$ & $\begin{array}{c}-0.051^{* * *} \\
(0.004)\end{array}$ & $\begin{array}{c}0.077^{* * *} \\
(0.007)\end{array}$ & $\begin{array}{c}-0.053^{* * *} \\
(0.004)\end{array}$ \\
\hline pr_ws & $\begin{array}{c}0.318^{* * *} \\
(0.007)\end{array}$ & $\begin{array}{c}-0.249 * * * \\
(0.006)\end{array}$ & $\begin{array}{c}0.333^{* * *} \\
(0.007)\end{array}$ & $\begin{array}{c}-0.263^{* * *} \\
(0.006)\end{array}$ & $\begin{array}{c}0.315^{* * *} \\
(0.007)\end{array}$ & $\begin{array}{c}-0.251^{* * *} \\
(0.006)\end{array}$ & $\begin{array}{c}0.321^{* * *} \\
(0.007)\end{array}$ & $\begin{array}{c}-0.257^{* * *} \\
(0.006)\end{array}$ \\
\hline pr_man & $\begin{array}{c}0.045^{* * *} \\
(0.007)\end{array}$ & $\begin{array}{c}-0.035^{* * *} \\
(0.005)\end{array}$ & $\begin{array}{c}0.043^{* * *} \\
(0.007)\end{array}$ & $\begin{array}{c}-0.034^{* * *} \\
(0.005)\end{array}$ & $\begin{array}{c}0.048^{* * *} \\
(0.006)\end{array}$ & $\begin{array}{c}-0.038^{* * *} \\
(0.005)\end{array}$ & $\begin{array}{c}0.043^{* * *} \\
(0.007)\end{array}$ & $\begin{array}{c}-0.034^{* * *} \\
(0.005)\end{array}$ \\
\hline Taylor 12 & $\begin{array}{c}0.019^{* * *} \\
(0.004)\end{array}$ & $\begin{array}{c}-0.014^{* * *} \\
(0.003)\end{array}$ & $\begin{array}{c}0.022^{* * *} \\
(0.004)\end{array}$ & $\begin{array}{c}-0.017^{* * *} \\
(0.003)\end{array}$ & $\begin{array}{c}0.019^{* * *} \\
(0.004)\end{array}$ & $\begin{array}{c}-0.015^{* * *} \\
(0.003)\end{array}$ & $\begin{array}{c}0.021^{* * *} \\
(0.004)\end{array}$ & $\begin{array}{c}-0.016^{* * *} \\
(0.003)\end{array}$ \\
\hline Taylor24 & $\begin{array}{c}-0.020^{* * *} \\
(0.004)\end{array}$ & $\begin{array}{c}0.016^{* * *} \\
(0.003)\end{array}$ & $\begin{array}{c}-0.015^{* * *} \\
(0.004)\end{array}$ & $\begin{array}{c}0.012^{* * *} \\
(0.003)\end{array}$ & $\begin{array}{c}-0.016^{* * *} \\
(0.004)\end{array}$ & $\begin{array}{c}0.013 * * * \\
(0.003)\end{array}$ & $\begin{array}{c}-0.017^{* * *} \\
(0.004)\end{array}$ & $\begin{array}{c}0.014^{* * *} \\
(0.003)\end{array}$ \\
\hline winter & $\begin{array}{c}0.007 \\
(0.005)\end{array}$ & $\begin{array}{l}-0.005 \\
(0.004)\end{array}$ & $\begin{array}{c}0.003 \\
(0.005)\end{array}$ & $\begin{array}{l}-0.002 \\
(0.004)\end{array}$ & $\begin{array}{c}0.002 \\
(0.005)\end{array}$ & $\begin{array}{l}-0.002 \\
(0.004)\end{array}$ & $\begin{array}{c}0.003 \\
(0.005)\end{array}$ & $\begin{array}{l}-0.002 \\
(0.004)\end{array}$ \\
\hline summer & $\begin{array}{c}0.000 \\
(0.005)\end{array}$ & $\begin{array}{c}0.000 \\
(0.004)\end{array}$ & $\begin{array}{l}-0.003 \\
(0.005)\end{array}$ & $\begin{array}{c}0.002 \\
(0.004)\end{array}$ & $\begin{array}{c}0.005 \\
(0.005)\end{array}$ & $\begin{array}{l}-0.004 \\
(0.004)\end{array}$ & $\begin{array}{c}0.003 \\
(0.005)\end{array}$ & $\begin{array}{l}-0.002 \\
(0.004)\end{array}$ \\
\hline fall & $\begin{array}{c}-0.006 \\
(0.005)\end{array}$ & $\begin{array}{c}0.005 \\
(0.004)\end{array}$ & $\begin{array}{l}-0.008 \\
(0.005)\end{array}$ & $\begin{array}{c}0.006 \\
(0.004)\end{array}$ & $\begin{array}{c}-0.008^{*} \\
(0.005)\end{array}$ & $\begin{array}{c}0.006^{*} \\
(0.004)\end{array}$ & $\begin{array}{c}0.003 \\
(0.005)\end{array}$ & $\begin{array}{c}-0.002 \\
(0.004)\end{array}$ \\
\hline $\begin{array}{l}\text { Log.-Lik. } \\
\text { Obs. } \\
\text { Ps.-R2 }\end{array}$ & $\begin{array}{c}-41420 \\
46611 \\
0.126\end{array}$ & & $\begin{array}{c}-41882 \\
46611 \\
0.116\end{array}$ & & $\begin{array}{c}-40953 \\
45683 \\
0.117\end{array}$ & & $\begin{array}{l}-4182 \\
45683 \\
0.114\end{array}$ & \\
\hline
\end{tabular}

Robust standard errors in parentheses. $* * * \mathrm{p}<0.01,{ }^{*} \mathrm{p}<0.05,{ }^{*} \mathrm{p}<0.1$. The table reports marginal effects for the outcomes "price increase" and "price decrease", respectively, setting all variables at their mean. For binary regressors, the effect is for discrete change from 0 to 1 . I additionally include but don't report firm-specific averages of the individualspecific variables, sectoral dummies as well as Taylor dummies for six and 18 months, respectively. (3a): including the cumulative rate of change of the aggregate rate of CPI inflation, (3b): excluding firm-specific means of idiosyncratic variables, (3c): idiosyncratic variables enter in first lags, (3d): macroeconomic variables included as month-on-month changes. 
Table B.10: Robustness Checks - Ordered Probit Regressions, Including Time-Specific Effects

\begin{tabular}{|c|c|c|}
\hline & \multicolumn{2}{|c|}{ Including time-specific effect } \\
\hline & Incr & Decr \\
\hline statebus $^{-}$ & $\begin{array}{c}-0.026^{* * *} \\
(0.004)\end{array}$ & $\begin{array}{c}0.021^{* * *} \\
(0.003)\end{array}$ \\
\hline busvol - & $\begin{array}{c}-0.038^{* * *} \\
(0.005)\end{array}$ & $\begin{array}{c}0.031^{* * *} \\
(0.004)\end{array}$ \\
\hline orders $^{-}$ & $\begin{array}{c}-0.030^{* * *} \\
(0.004)\end{array}$ & $\begin{array}{c}0.025^{* * *} \\
(0.004)\end{array}$ \\
\hline busdev $^{-}$ & $\begin{array}{c}-0.032^{* * *} \\
(0.004)\end{array}$ & $\begin{array}{c}0.026^{* * *} \\
(0.004)\end{array}$ \\
\hline statebus $^{+}$ & $\begin{array}{l}0.011^{*} \\
(0.006)\end{array}$ & $\begin{array}{c}-0.009^{*} \\
(0.005)\end{array}$ \\
\hline busvol $^{+}$ & $\begin{array}{c}0.002 \\
(0.005)\end{array}$ & $\begin{array}{l}-0.002 \\
(0.004)\end{array}$ \\
\hline orders $^{+}$ & $\begin{array}{c}-0.039 * * * \\
(0.007)\end{array}$ & $\begin{array}{c}0.034^{* * *} \\
(0.007)\end{array}$ \\
\hline busdev $^{+}$ & $\begin{array}{c}-0.036^{* * *} \\
(0.006)\end{array}$ & $\begin{array}{c}0.032^{* * *} \\
(0.006)\end{array}$ \\
\hline pr_ws & $\begin{array}{c}0.284^{* * *} \\
(0.008)\end{array}$ & $\begin{array}{c}-0.229^{* * * *} \\
(0.006)\end{array}$ \\
\hline pr_m & $\begin{array}{c}0.109^{* * *} \\
(0.041)\end{array}$ & $\begin{array}{c}-0.088^{* * * *} \\
(0.033)\end{array}$ \\
\hline Taylor 12 & $\begin{array}{c}0.014^{* * *} \\
(0.004)\end{array}$ & $\begin{array}{c}-0.011^{* * *} \\
(0.003)\end{array}$ \\
\hline Taylor6 & $\begin{array}{c}0.000 \\
(0.004)\end{array}$ & $\begin{array}{c}0.000 \\
(0.003)\end{array}$ \\
\hline summer & $\begin{array}{l}-0.079 \\
(0.048)\end{array}$ & $\begin{array}{c}0.070 \\
(0.047)\end{array}$ \\
\hline winter & $\begin{array}{c}0.095^{* *} \\
(0.044)\end{array}$ & $\begin{array}{c}-0.068^{* *} \\
(0.028)\end{array}$ \\
\hline fall & $\begin{array}{l}0.086^{*} \\
(0.049)\end{array}$ & $\begin{array}{c}-0.063^{*} \\
(0.032)\end{array}$ \\
\hline $\begin{array}{l}\text { Log-Lik. } \\
\text { Obs. } \\
\text { Ps.-R2 }\end{array}$ & $\begin{array}{c}-45352.474 \\
50904 \\
0.145 \\
\end{array}$ & \\
\hline $\begin{array}{l}\text { Wald Test of } \\
\text { Joint Sign. }\end{array}$ & Prob $>$ chi & .0000 \\
\hline
\end{tabular}

Robust standard errors in parentheses. ${ }^{* * *} \mathrm{p}<0.01,{ }^{*} \mathrm{p}<0.05,{ }^{*} \mathrm{p}<0.1$. The table reports marginal effects for the outcomes "price increase" and "price decrease", respectively, setting all variables at their mean. For binary regressors, the effect is for discrete change from 0 to 1 . I additionally include but don't report firm-specific averages of the individual-specific variables, sectoral dummies as well as Taylor dummies for six and 18 months, respectively. Moreover, time-specific effects are included. 
Table B.11: Different Estimation Methods - Price Realizations

\begin{tabular}{|c|c|c|c|c|c|}
\hline & \multicolumn{2}{|c|}{ Logit } & \multicolumn{3}{|c|}{ Linear Regression } \\
\hline & Increases & Decreases & Pooled & Fixed Effects & IV Regression \\
\hline statebus $^{-}$ & $\begin{array}{c}-0.025^{* * *} \\
(0.005)\end{array}$ & $\begin{array}{c}0.031^{* * *} \\
(0.004)\end{array}$ & $\begin{array}{c}-0.064^{* * *} \\
(0.007)\end{array}$ & $\begin{array}{c}-0.047^{* * *} \\
(0.007)\end{array}$ & $\begin{array}{c}-0.049^{*} \\
(0.026)\end{array}$ \\
\hline busvol $^{-}$ & $\begin{array}{l}-0.003 \\
(0.005)\end{array}$ & $\begin{array}{c}0.002 \\
(0.004)\end{array}$ & $\begin{array}{l}-0.002 \\
(0.007)\end{array}$ & $\begin{array}{c}-0.018^{* * *} \\
(0.007)\end{array}$ & $\begin{array}{c}0.149^{* *} \\
(0.070)\end{array}$ \\
\hline orders $^{-}$ & $\begin{array}{c}-0.022^{* * *} \\
(0.005)\end{array}$ & $\begin{array}{c}0.035^{* * *} \\
(0.004)\end{array}$ & $\begin{array}{c}-0.069^{\text {*** }} \\
(0.007)\end{array}$ & $\begin{array}{c}-0.036^{* * *} \\
(0.007)\end{array}$ & $\begin{array}{c}-0.167^{* * *} \\
(0.021)\end{array}$ \\
\hline busdev $^{-}$ & $\begin{array}{c}-0.015^{* *} \\
(0.006)\end{array}$ & $\begin{array}{c}0.044^{* * *} \\
(0.005)\end{array}$ & $\begin{array}{c}-0.069^{* * *} \\
(0.007)\end{array}$ & $\begin{array}{c}-0.032^{* * *} \\
(0.007)\end{array}$ & $\begin{array}{c}-0.130^{* * *} \\
(0.020)\end{array}$ \\
\hline statebus $^{+}$ & $\begin{array}{c}0.025^{* * *} \\
(0.007)\end{array}$ & $\begin{array}{c}0.009 \\
(0.006)\end{array}$ & $\begin{array}{c}0.032^{* * *} \\
(0.010)\end{array}$ & $\begin{array}{c}0.024^{* *} \\
(0.009)\end{array}$ & $\begin{array}{c}0.651^{* *} \\
(0.028)\end{array}$ \\
\hline busvol $^{+}$ & $\begin{array}{c}0.028^{* * *} \\
(0.006)\end{array}$ & $\begin{array}{c}-0.037^{* * *} \\
(0.004)\end{array}$ & $\begin{array}{c}0.071^{* * *} \\
(0.008)\end{array}$ & $\begin{array}{c}0.028^{* * *} \\
(0.007)\end{array}$ & $\begin{array}{c}0.023 \\
(0.100)\end{array}$ \\
\hline orders $^{+}$ & $\begin{array}{c}-0.015^{*} \\
(0.008)\end{array}$ & $\begin{array}{c}0.044^{* * *} \\
(0.008)\end{array}$ & $\begin{array}{c}-0.035^{* * *} \\
(0.011)\end{array}$ & $\begin{array}{l}-0.017 \\
(0.012)\end{array}$ & $\begin{array}{l}-0.183 \\
(0.030)\end{array}$ \\
\hline busdev $^{+}$ & $\begin{array}{c}-0.014^{* *} \\
(0.007) \\
\end{array}$ & $\begin{array}{c}0.053^{* * *} \\
(0.007)\end{array}$ & $\begin{array}{c}-0.055^{* * *} \\
(0.010)\end{array}$ & $\begin{array}{c}-0.022^{* *} \\
(0.010) \\
\end{array}$ & $\begin{array}{c}-0.169^{* * *} \\
(0.033)\end{array}$ \\
\hline inflation & $\begin{array}{c}0.024^{* * *} \\
(0.005)\end{array}$ & $\begin{array}{c}0.002 \\
(0.004)\end{array}$ & $\begin{array}{c}0.022^{* * *} \\
(0.007)\end{array}$ & $\begin{array}{c}0.013^{* *} \\
(0.006)\end{array}$ & $\begin{array}{c}0.019^{* *} \\
(0.008)\end{array}$ \\
\hline oil & $\begin{array}{c}-0.280^{* * *} \\
(0.023)\end{array}$ & $\begin{array}{c}-0.253^{* * *} \\
(0.018)\end{array}$ & $\begin{array}{c}0.090^{* * *} \\
(0.030)\end{array}$ & $\begin{array}{c}0.007 \\
(0.030)\end{array}$ & $\begin{array}{c}0.167^{* * *} \\
(0.034)\end{array}$ \\
\hline exchrate & $\begin{array}{c}-0.022 \\
(0.031)\end{array}$ & $\begin{array}{c}-0.011 \\
(0.022)\end{array}$ & $\begin{array}{c}0.048 \\
(0.011)\end{array}$ & $\begin{array}{l}-0.012 \\
(0.041)\end{array}$ & $\begin{array}{c}0.108^{* *} \\
(0.044)\end{array}$ \\
\hline EUR & $\begin{array}{c}0.060^{* * *} \\
(0.012)\end{array}$ & $\begin{array}{l}-0.004 \\
(0.007)\end{array}$ & $\begin{array}{c}0.061^{* * *} \\
(0.013)\end{array}$ & $\begin{array}{c}0.066^{* * *} \\
(0.013)\end{array}$ & $\begin{array}{c}0.082^{* * *} \\
(0.015)\end{array}$ \\
\hline VAT & $\begin{array}{c}0.089^{* * *} \\
(0.008)\end{array}$ & $\begin{array}{c}-0.039^{* * *} \\
(0.004)\end{array}$ & $\begin{array}{c}0.120^{* * *} \\
(0.010)\end{array}$ & $\begin{array}{c}0.096 * * * \\
(0.009)\end{array}$ & $\begin{array}{c}0.108^{* * *} \\
(0.010)\end{array}$ \\
\hline pr_ws & $\begin{array}{c}0.315^{* * *} \\
(0.008)\end{array}$ & $\begin{array}{c}-0.212^{* *} \\
(0.006)\end{array}$ & $\begin{array}{c}0.552^{* * *} \\
(0.011)\end{array}$ & $\begin{array}{c}0.552^{* * *} \\
(0.012)\end{array}$ & $\begin{array}{c}0.540^{* * *} \\
(0.012)\end{array}$ \\
\hline pr_man & $\begin{array}{c}0.121^{* * *} \\
(0.008)\end{array}$ & $\begin{array}{c}0.013^{* * *} \\
(0.006) \\
\end{array}$ & $\begin{array}{c}0.071^{* * *} \\
(0.011)\end{array}$ & $\begin{array}{c}0.061^{* * * *} \\
(0.010)\end{array}$ & $\begin{array}{c}0.049^{* * * *} \\
(0.012)\end{array}$ \\
\hline Taylor12 & $\begin{array}{c}0.122^{* * *} \\
(0.005)\end{array}$ & $\begin{array}{c}0.074^{* *} \\
(0.004)\end{array}$ & $\begin{array}{c}0.021^{* * *} \\
(0.006)\end{array}$ & $\begin{array}{c}0.006 \\
(0.006)\end{array}$ & $\begin{array}{c}0.015^{* *} \\
(0.007)\end{array}$ \\
\hline Taylor 24 & $\begin{array}{c}0.051^{* * *} \\
(0.005)\end{array}$ & $\begin{array}{c}0.060^{* *} \\
(0.004)\end{array}$ & $\begin{array}{c}-0.027^{* * *} \\
(0.007)\end{array}$ & $\begin{array}{c}-0.043^{* * *} \\
(0.006)\end{array}$ & $\begin{array}{c}-0.045^{* * *} \\
(0.007)\end{array}$ \\
\hline winter & $\begin{array}{c}0.031^{* * *} \\
(0.006)\end{array}$ & $\begin{array}{c}0.019^{* *} \\
(0.005)\end{array}$ & $\begin{array}{c}0.005 \\
(0.008)\end{array}$ & $\begin{array}{c}0.012^{* *} \\
(0.007)\end{array}$ & $\begin{array}{c}-0.002 \\
(0.009)\end{array}$ \\
\hline summer & $\begin{array}{c}0.016^{* *} \\
(0.006)\end{array}$ & $\begin{array}{c}0.007 \\
(0.005)\end{array}$ & $\begin{array}{c}0.005 \\
(0.008)\end{array}$ & $\begin{array}{c}0.010 \\
(0.007)\end{array}$ & $\begin{array}{l}-0.006 \\
(0.014)\end{array}$ \\
\hline fall & $\begin{array}{c}-0.013^{* *} \\
(0.006) \\
\end{array}$ & $\begin{array}{l}-0.003 \\
(0.005) \\
\end{array}$ & $\begin{array}{c}-0.014 \\
(0.008) \\
\end{array}$ & $\begin{array}{c}-0.004 \\
(0.008) \\
\end{array}$ & $\begin{array}{c}0.016 \\
(0.031) \\
\end{array}$ \\
\hline $\begin{array}{l}\text { Log-Lik. } \\
\text { Obs. } \\
\text { Ps.-R2 }\end{array}$ & $\begin{array}{c}-22221 \\
46611 \\
0.191\end{array}$ & $\begin{array}{c}-18184 \\
46611 \\
0.222\end{array}$ & $\begin{array}{l}46611 \\
0.209\end{array}$ & $\begin{array}{l}46611 \\
0.161\end{array}$ & $\begin{array}{l}46611 \\
0.186\end{array}$ \\
\hline
\end{tabular}

Robust standard errors in parentheses. ${ }^{* * *} \mathrm{p}<0.01,{ }^{* *} \mathrm{p}<0.05,{ }^{*} \mathrm{p}<0.1$. Columns 2 and 3 report marginal effects from a pooled logit regression for price increases and decreases, respectively. Marginal effects are computed by setting all variables at their mean. For binary regressors, the effect is for discrete change from 0 to 1 . Column 4 reports coefficients from a linear regression. Column 5 reports coefficients from a linear panel regression with fixed effects. Column 6 reports coefficients from a linear instrumental variables regression using a 2SLS estimator with busvol ${ }^{-}$,

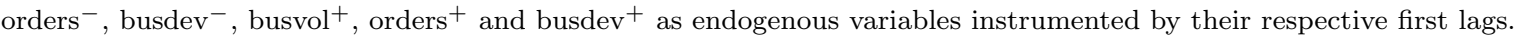




\section{References}

Abberger, K., Birnbrich, M., and Seiler, C. (2009). "Der test des tests im handel eine metaumfrage zum ifo konjunkturtest." Ifo Schnelldienst, 62(21), 34-41.

Alvarez, F. E., Lippi, F., and Paciello, L. (2010). "Optimal price setting with observation and menu costs." NBER Working Papers 15852, National Bureau of Economic Research, Inc.

Aucremanne, L., and Dhyne, E. (2005). "Time-dependent versus state-dependent pricing: A panel data approach to the determinants of belgian consumer price changes." Research series 200504-1, National Bank of Belgium.

Basu, S. (1995). "Intermediate goods and business cycles: Implications for productivity and welfare." American Economic Review, 85(3), 512-31.

Becker, S. O., and Wohlrabe, K. (2008). "Micro data at the ifo institute for economic research - the "ifo business survey", usage and access." Journal of Applied Social Sciences, 128(2), 307-319.

Blanchard, O. J. (1983). "Inflexible relative prices and price level inertia." NBER Working Papers 1147, National Bureau of Economic Research, Inc.

Blinder, A. S. (1991). "Why are prices sticky? preliminary results from an interview study." American Economic Review, 81(2), 89-96.

Bonomo, M., and Carvalho, C. (2004). "Endogenous time-dependent rules and inflation inertia." Journal of Money, Credit and Banking, 36(6), 1015-41.

Bonomo, M., Carvalho, C., and Garcia, R. (2010). "State-dependent pricing under infrequent information: a unified framework." Staff Reports 455, Federal Reserve Bank of New York.

Burstein, A. T. (2006). "Inflation and output dynamics with state-dependent pricing decisions." Journal of Monetary Economics, 53(7), 1235-1257.

Caballero, R. (1989). "Time dependent rules, aggregate stickiness and information externalities." Discussion Papers 1989-11, Columbia University, Department of Economics.

Calvo, G. A. (1983). "Staggered prices in a utility-maximizing framework." Journal of Monetary Economics, $12(3), 383-398$.

Cameron, A. C., and Trivedi, P. K. (2007). Microeconometrics: Methods and Applications. Cambridge University Press, New York.

Caplin, A. S., and Spulber, D. F. (1987). "Menu costs and the neutrality of money." The Quarterly Journal of Economics, 102(4), 703-25.

Card, D., and Sullivan, D. G. (1988). "Measuring the effect of subsidized training programs on movements in and out of employment." Econometrica, 56(3), 497-530.

Cecchetti, S. G. (1986). "The frequency of price adjustment : A study of the newsstand prices of magazines." Journal of Econometrics, 31(3), 255-274.

Clark, T. E. (1999). "The responses of prices at different stages of production to monetary policy shocks." The Review of Economics and Statistics, 81(3), 420-433.

Dhyne, E., Alvarez, L. J., Bihan, H. L., Veronese, G., Dias, D., Hoffmann, J., Jonker, N., Lunnemann, P., Rumler, F., and Vilmunen, J. (2006). "Price changes in the euro area and the united states: Some facts from individual consumer price data." Journal of Economic Perspectives, 20(2), 171-192.

Dotsey, M., King, R. G., and Wolman, A. L. (1999). "State-dependent pricing and the general equilibrium dynamics of money and output." The Quarterly Journal of Economics, 114(2), 655-690.

Eichenbaum, M., Jaimovich, N., and Rebelo, S. (2010). "Reference prices and nominal rigidities." American Economic Review, forthcoming.

Fabiani, S., Druant, M., Hernando, I., Kwapil, C., Landau, B., Loupias, C., Martins, F., Math, T., Sabbatini, R., Stahl, H., and Stokman, A. (2006). "What firms' surveys tell us about price-setting behavior in the euro area." International Journal of Central Banking, 2(3).

Gertler, M., and Leahy, J. (2008). "A phillips curve with an ss foundation." Journal of Political Economy, (3), 533-572.

Golosov, M., and Lucas, R. E. (2007). "Menu costs and phillips curves." Journal of Political Economy, 115, $171-199$.

Hoffmann, J., and Kurz-Kim, J.-R. (2006). "Consumer price adjustment under the microscope - germany in a period of low inflation." Working Paper Series 652, European Central Bank.

Huang, K. X. D., and Liu, Z. (2001). "Production chains and general equilibrium aggregate dynamics." Journal of Monetary Economics, 48(2), 437-462.

Klenow, P. J., and Kryvtsov, O. (2008). "State-dependent or time-dependent pricing: Does it matter for recent u.s. inflation?" The Quarterly Journal of Economics, 123(3), 863-904.

Lein, S. M. (2010). "When do firms adjust prices? evidence from micro panel data." Journal of Monetary Economics, 57(6), $696-715$.

Lombardo, G., and Vestin, D. (2008). "Welfare implications of calvo vs. rotemberg-pricing assumptions." Economics Letters, 100(2), 275-279. 
Loupias, C., and Sevestre, P. (2010). "Costs, demand, and producer price changes." Working Paper Series 1184, European Central Bank.

Mackowiak, B., and Wiederholt, M. (2009). "Optimal sticky prices under rational inattention." American Economic Review, 99(3), 769-803.

Mackowiak, B. A., Moench, E., and Wiederholt, M. (2009). "Sectoral price data and models of price setting." CEPR Discussion Papers 7339, C.E.P.R. Discussion Papers.

Mackowiak, B. A., and Smets, F. (2008). "On implications of micro price data for macro models." CEPR Discussion Papers 6961, C.E.P.R. Discussion Papers.

Mankiw, N. G., and Reis, R. (2002). "Sticky information versus sticky prices: A proposal to replace the new keynesian phillips curve." The Quarterly Journal of Economics, 117(4), 1295-1328.

Mankiw, N. G., and Reis, R. (2006). "Pervasive stickiness." American Economic Review, 96(2), 164-169.

Mankiw, N. G., and Reis, R. (2010). "Imperfect information and aggregate supply." NBER Working Papers 15773 , National Bureau of Economic Research, Inc.

Midrigan, V. (2007). "Menu costs, multi-product firms, and aggregate fluctuations." Cfs working paper studies, Center for Financial Series.

Mundlak, Y. (1978). "On the pooling of time series and cross section data." Econometrica, 46(1), 69-85.

Nakamura, E. (2008). "Pass-through in retail and wholesale." American Economic Review, 98(2), 430-37.

Nakamura, E., and Steinsson, J. (2008a). "Five facts about prices: A reevaluation of menu cost models." The Quarterly Journal of Economics, 123(4), 1415-1464.

Nakamura, E., and Steinsson, J. (2008b). "Monetary non-neutrality in a multi-sector menu cost model." NBER Working Papers 14001, National Bureau of Economic Research, Inc.

Sajaia, Z. (2008). "Maximum likelihood estimation of a bivariate ordered probit model: implementation and monte carlo simulations." The Stata Journal, 4(2), 1-18.

Stahl, H. (2010). "Price adjustment in german manufacturing: evidence from two merged surveys." Managerial and Decision Economics, 31(2-3), 67-92.

Taylor, J. B. (1980). "Aggregate dynamics and staggered contracts." Journal of Political Economy, 88(1), 1-23.

Vermeulen, P., Dias, D., Sabbatini, R., Dossche, M., Stahl, H., Gautier, E., and Hernando, I. (2007). "Price setting in the euro area: some stylised facts from individual producer price data." Discussion Paper Series 1: Economic Studies 2007,03, Deutsche Bundesbank Research Centre.

Wooldridge, J. M. (2005). "Simple solutions to the initial conditions problem in dynamic, nonlinear panel data models with unobserved heterogeneity." Journal of Applied Econometrics, 20(1), 39-54. 